\title{
REPRODUCTION IN THE LESSER HORSESHOE BAT
}

\author{
(Rhinolophus hipposideros hipposideros Bechstein, 1800)
}

by

\author{
J I R I G A I S L E R \\ (Institute of Vertebrate Zoology, Czechoslovak Academy of Sciences, Brno)
}

\begin{abstract}
CONTENTS
Introduction . . . . . . . . . . . . . . 45

Material and methods . . . . . . . . . . 45

Brief description of the reproductive organs . . . 46

The male sexual cycle . . . . . . . . . . . 47

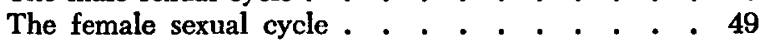

Sexual maturity . . . . . . . . . . . . . 51

Notes on population dynamics . . . . . . . 55

Discussion . . . . . . . . . . . . . . 56

Summary . . . . . . . . . . . . 60

References . . . . . . . . . . . . 61
\end{abstract}

\section{INTRODUCTION}

Although the literature on the reproduction of European bats is rather numerous, we lack such a detailed year-round description of the sexual cycle and reproductive habits of certain bat species as PEArson, Koford and Pearson (1952) published on the North American bat Corynorhinus (= Plecotus) rafinesquei. The kind proposal of Prof. Dr. E. J. Slijper (Amsterdam) enabled me to sum up the results of my investigation on reproduction of the lesser horseshoe bat Rhinolophus hipposideros 'henceforward, R.h.) in one synthetic paper. Thus the present study is based on my previous papers on male and female sexual cycles in R.h. (Gaister and Titrbach, 1964; Gaisler, 1965), completed by additional data on the anatomy of reproductive organs and some others. The tables summarizing numerical data on the male and female reproductive organs, the banding results as well as some merely descriptive parts will not be reprinted here and, in this respect, I would like to draw the reader's attention to the two above mentioned papers. As the material has been collected exclusively on the territory of Czechoslovakia, the observed phenomena refer to this country only. However, the described scheme is very likely valid for other populations of R.h., at least those inhabiting Middle Europe.

It is my pleasant duty to thank Prof. Dr. J. Kratochvil, for facilities enabling this investigation, and Dr. M. Titlbach, who introduced me into histological work and made some of the photomicrographs of this paper.

\section{MATERIALS AND METHODS}

I examined a total of 149 individuals, of which 45 were adult males, 19 young males, 56 adult females and 29 young females. This material was collected during 1959 and 1960 in central Moravia. With respect to the frequent occurrence of the species in this area, I refrain from enumerating the individual localities. The distribution of my material according to dates of collections is seen in Figs. 9 (males) and 33 (females).

In all individuals caught, I first examined their colour and the appearance of their external genitals. In the males, the right testis was weighed in fresh state. The testes, epididymides and the unpaired urethral glands were examined from histological point of view. In the females, I measured the length of their pectoral and anchoring (false) nipples and the width of their vaginal opening. The ovaries, oviducts, uteri and vaginae were examined histologically; in certain individuals, only some of these organs could be examined due to various reasons. The material was fixed in Bouin's picro-formaldehyde or 4 per cent formaldehyde and sectioned after being embedded in paraffin wax or gelatin. The following methods were used in staining: Heidenhain's iron haematoxylin; Azane; haematoxylin-eosin; the PAS reaction; haematoxylin-oleic red; and the contact haematoxylin method (after Worf, 1954).

Apart from the material treated in this way, a part of the information was obtained from additional material collected during 1962-1966. Besides, I uti- 


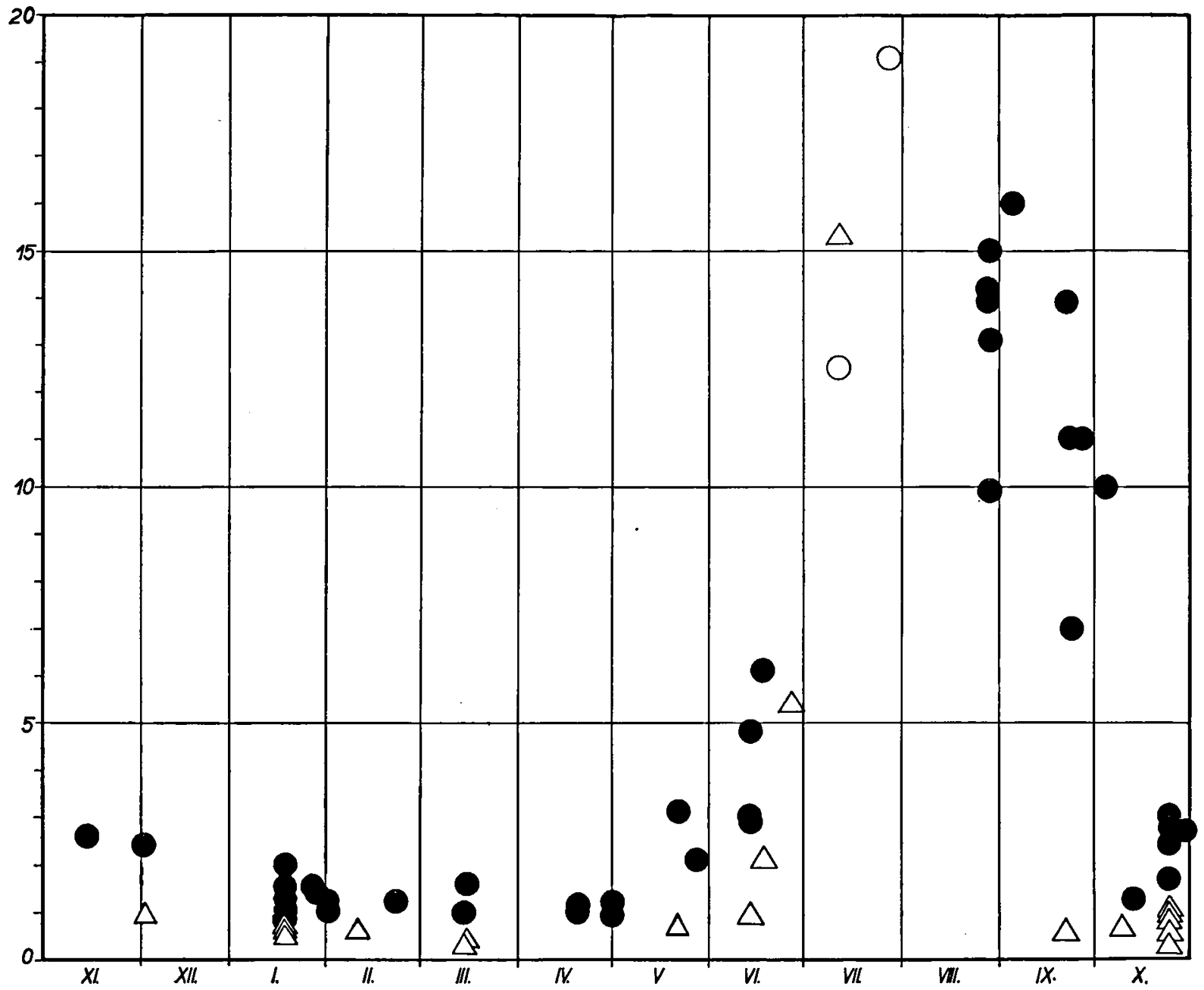

Fig. 9. Variation of weight of the testes during a year. Ordinate, weight of right testis, mg.; abscissa, months; dots, adult males with spermatozoa present in smears from cauda epididymidis; rings, adults with spermatozoa absent from those smears; triangles, subadult males.

lized some of the results of my field work, especially those obtained by banding some 5,000 individuals of R.h.

\section{BRIEF DESCRIPTION OF THE REPRODUCTIVE ORGANS}

The male

RoBin (1881b) was the only author to study in detail the anatomy of male reproductive organs in the family Rhinolophidae. Among other important observations, he discovered a peculiar male accessory gland which he called the glandula urethralis. This gland is also present in some other Microchiroptera (Grasse, 1955, etc.) as well as in Megachiroptera (VAMBurKar, 1958) but does not occur in the European Vesperti- lionidae. Some details of the extensive Robis's description suggest the posibility that he never had an adult male Rhinolophid bat in full sexual activity. Thus, according to RoBIN, “... les testicules sont relativement petits ... leur volume varie du simple au double suivant qu'ils sont en activité ou non". However, as shown in Fig. 9 of the present paper, the weight of a testis in adult $R$.h. varies considerably during a year, from about 1 to $19 \mathrm{mg}$. Furthermore, in Fig. 34 (Planche 5) of the RoBis's paper, the male reproductive organs of Rhinolophus ferrumequinum collected "au commencement de l'hiver" are shown, this drawing being reprinted in Grassé (1955). I suppose this drawing refers to a subadult male as there are extreme similarities to the winter condition of a 
subadult, and differences from that of adult male R.h. There seems to be no illustration of the adult male genital tract in R.h. having been published until now.

Figs. 1 and 2 (Plate I) show the situation in hibernating adult male, i.e. the resting testes, epididymides filled with sperm and highly developed sex accessories. A comparison with the situation in subadult male at the same season (Fig. 3) shows great differences in the dimensions of the organs, their position, however, is practically the same. The immature testes are situated more cranially than the mature ones but I did not observe signs of seasonal descensus testiculorum in connection with sexual activity. In adult males, a scrotal rudiment is formed which contains cauda epididymidis (Fig. 34). The testes of adults are strongly enlarged in summer, especially during the months of July and August (cf. Fig. 9). On the contrary, the condition of the mature sex accessories during the summer period resembles the one of subadult males in winter.

The sex accessories of $R . h$. consist of glandulae ampullares, glandulae vesiculosae (seminal vesicles), prostata, glandula urethralis and glandulae bulbourethrales. There seems to be little if any difference in the microscopical structure between the ampullar glands and seminal vesicles. The urethral gland is the greatest element of the male genital tract, reaching the length of ca. $5.5 \mathrm{~mm}$. and the weight of ca. $25 \mathrm{mg}$. The difference in volume between the active and inactive incl. immature urethral gland is substantial (Fig. 4). On the contrary, the bulbourethral or Cowper's glands of R.h. are very small.

\section{The female}

RoBIN (1881b) described the female reproductive organs of Rhinolophidae and Matthews-Harrison (1937) dealt with the structure of the female genitalia in British horseshoe bats, Rhinolophus ferrumequinum insulanus and Rhinolophus hipposideros minutus. In the paper by Suurrer (1960), two photographs of a part of the female genitalia of R.h. are given. I will only summarize and complete the observations of the mentioned authors. According to the classification of Wood-Jones (1917), female Rhinolophus belong to the type with a transverse opening to the vulva (cf. Plate VII, Figs. 36, 37) and the uterine horns about equal to the length of the corpus uteri. In R.h. the uterine horns are distinctly longer than the body of the uterus, being still much shorter than in some Molossidae and Emballonuridae. The uterus is bicornis non subseptus.
Figs. 5 and 6 (Plate II) demonstrate the reproductive organs of adult female; Figs. 7 and 8 , those of subadult female R.h. These photographs relate to hibernating specimens. The ovaries are surrounded by a peritoneal capsule in the wall of which the oviducts or fallopian tubes follow to describe nearly a complete circle so that they are not distinctly visible on the photographs. In the adult parous specimen, the right uterine horn is always somewhat enlarged. The uterus reaches its maximal volume during the period of pregnancy, attaining ca. $25 \mathrm{~mm}$. in diameter and $2.3 \mathrm{~g}$. in weight shortly before parturition. At that time, the uterus weight (incl. the fetus) comprises about one fifth of the body weight. The vagina of adult inseminated female is remarkably large partly due to the presence of a vaginal plug. During the hibernating period, the length of the vagina averages $6.5 \mathrm{~mm}$. and its weight is about $49 \mathrm{mg}$. During the summer months, the mature vagina becomes much smaller and resembles the immature one.

\section{THE MALE SEXUAL CYCLE}

\section{The testis}

The first signs of commencing spermatogenesis are found in May, after the change from winter torpidity to active life (Plate III, Fig. 10). Macroscopically, the testes are somewhat enlarged. Their tunica albuginea is comparatively thick, the interstitial connective tissue rather solid. The basal pellicle of the seminiferous tubules is still rather thick although the tubules themselves are more voluminous compared to the winter period. The seminiferous epithel consists, close to the basal pellicle, of rather dense spermatogonia and numerous Sertoli cells. Various mitotic figures are observed in the nuclei of the spermatogonia especially after staining with Heidenhain's iron haematoxylin. The interstitial tissue contains voluminous groups of cells of Leydig. Their cytoplasm is conspicuously light, foamy, but containing minute granules in places. The nuclei are spherical, a little darker due to the presence of chromatin granules, with the intensively stained nucleoli clearly visible.

The spermatogenesis continues through June and July (Fig. 11), culminating towards the end of July and in August (Fig. 12). By that time, the testes have strongly increased in their size (cf. Fig. 9). Their tunica albuginea, compared with that of the resting testes, is considerably thinner, the seminiferous tubules are voluminous, the interstitial connective tissue is very thin and fine. The basal pellicle of the tubules is likewise fine. It is joined with a high layer of seminiferous cells in various stages of spermatocyto- 
and spermatohistogenesis, as seen in Fig. 12. Close to the basal pellicle lie the spermatogonia with spherical nuclei. Above this nearly continuous layer of basally situated cells, one can find another developmental type, the order I spermatocytes. Those lying basally are not much larger than the preceding cells as a rule but in the subsequent layers, one can find large cells of mostly polyhedral shape, with large nuclei containing typical chromatin loops and ribbons. Several further layers consist of substantially smaller order II spermatocytes. Close to the lumen of the tubules lie, as a rule, small spermatides whose minute spherical nuclei show a distinct chromatin structure. The lumen of the seminiferous tubules then contains various stages of the histogenetical development of the spermatozoa. However, all described types of cells are rarely contained in one and the same tubule at the same time. Individual tubules differ in the degree of spermatogenesis but nearly all contain even ripe spermatozoa. The individual Sertoli cells are completely suppressed by the numerous development stages of seminiferous cells. The interstitial cells of Leydig are found in small groups in the spaces between the tubules. Their cytoplasm is deeper staining, slightly foamy. Their nuclei are rather small, spherical, with rather distinct structure and clearly visible nucleoli.

I lack material from September (urifortunately, the September material of males could not be'treated histologically); however, the microscopical structure of the October testes indicates that the spermatogenesis lasts throughout September. In October, the picture is heterogenous, with spermatogenesis still present in some tubules and terminated in others again (Fig. 13). The basal pellicle of the tubules is fine, the spermatogonia are largely rather numerous, showing nuclei with conspicuous basophile nucleoli as a rule. The order I spermatocytes are present in single tubules, the order II spermatocytes are similarly scarce. Most of the tubules with active spermatogenesis contain spermatides and various stages of spermatohistogenesis including ripe spermatozoa which, in some cases, reach nearly to the basal pellicle of the tubules with their heads. On the contrary, the epithelium of certain tubules consists mostly of Sertoli cells with typical ovoid nuclei and distinct nucleoli. Some of these tubules contain, apart from the spermatogonia, individual order I spermatocytes or, incidentally, certain further developmental stages of the spermatogenesis, showing signs of degeneration. Groups of the interstitial cells are larger than in the previous months (cf. Figs. 12 and 13).
Their nuclei are comparatively deep staining, rich in chromatin granules among which the nucleolus is clearly visible. Their cytoplasm is foamy, light and containing minute non-confluent particles visible after staining for fats.

In November, the microscopical structure of the tubules slightly resembles that in May (Fig. 14). The canaliculi seminiferi contorti are rather tightly grouped, their basal pellicle is relatively thick. The cells lining the canaliculi are easily divided, by their shape and general appearance of their nuclei, into Sertoli cells (numerous) and spermatogonia (rather scarce). The lumen of the canaliculi is usually filled with very faintly staining foamy substance and scarce extinct seminiferous cells with nuclei frequently altered. The interstitial connective tissue is rich in cells with nuclei usually elongated and rather deeply staining. Apart from these are, in the places where several canaliculi meet one another, groups of interstitial cells of Leydig, with very light cytoplasm, spherical nuclei likewise light staining and with usually one distinct nucleolus.

In December, the spermatogenesis does not take place any more so that at that time, one may consider the testes as resting. The tunica albuginea is rather thick, the septa between the tubules are rather wide and rich in cells. Compared to the previous stage, the seminiferous tubules are still smaller, their epithelium again consisting of numerous Sertoli cells, forming several layers of nuclei, and of the spermatogonia. The interstitial tissue between the tubules contains rather voluminous groups of cells of Leydig. Their nuclei possess the typical chromatin pattern, their cytoplasm is light in colour, foamy, with great numbers of minute, non-confluent droplets of fat.

In the period January to April, the general microscopical structure of the testes hardly differs from that described in December. A difference is apparent only in the interstitial cells of Leydig which, during March and April, form large groups or continuous stripes in places, inserted between the seminiferous tubules in the interstitial connective tissue (Fig. 15). Their cytoplasm is filled with droplets of fat.

\section{The epididymis}

A feature characteristic of adult male R.h. is that the ducts of their sexual glands are never entirely free of spermatozoa. In July, spermatozoa were not found in smears from cauda epididymidis (cf. Fig. 9) but in the sections of most of the tubules of the epididymides the spermatozoa were present though scarce. 
During intensive spermatogenesis in July and August, the ductus epididymidis shows tubules not very wide, lined with cylindrical epithelium with stereociliae. Apart from single spermatozoa, the narrow lumina of the tubules in the cauda epididymidis contain small spherical cells with feebly staining cytoplasm and mostly minute, often eccentric, deep staining nuclei.

As appears from the smears from cauda epididymidis (Fig. 9), large numbers of spermatozoa appear in the ducts already by the end of August and in September. Histological observations were possible on the material from October. The initial segment of the ductus epididymidis with a high cylindrical epithelium contains small numbers of spermatozoa in the lumen; the terminal segment of the ductus epididymidis, lined with a nearly cubical epithelium, is overfilled with spermatozoa. A similar condition is found in the ducts of the epididymis during November when the lumina of the terminal segments of the ducts are considerably dilated by numbers of spermatozoa (Plate IV, Fig. 16). At that period, the ductuli efferentes contain epithelial cells of various height so that their lumina bear a characteristical starlike appearance. These lumina are empty or contain only single sperma:ozoa as a rule.

During winter, the microscopical structure of the ductuli efferentes and ductus epididymidis remains rather unchanged. It is generally observed that the numbers of spermatozoa decrease during the winter but as late as April the tubules of the cauda epididymidis are still filled with spermatozoa. in May, the decrease of their numbers in the ducts becomes conspicuous. In the middle section of the ductus epididymidis there are only single spermatozoa (Fig. 17). While the terminal sections still contain rather numerous spermatozoa, their numbers are considerably decreased compared to the previous months. The decrease in numbers of spermatozoa in the ducts of the epididymis, accompanied by a gradual narrowing of the ductus epididymidis, lasts until August when the ducts are filled again.

\section{The urethral gland}

This gland is resting through a great part of the year, approximately from April till August. At that period it consists of tubulous glandulae lined with a onelayer cylindrical epithelium (Fig. 19). The nuclei of the cells are slightly oval, not very deep staining, with rather few chromatin granules, lying rather in the periphery of the nucleus, and with only one nucleolus as a rule. The cytoplasm is very feebly staining with plasmatic stains. The lumen of the tubules is slightly starlike.

The first signs of changing microscopical structure of this gland were observed in October but very likely, they take place already during September as an increase in volume of the gland is observed at that period. The cells begin to fill with fine, minute granulae which are mostly oxyphile and most distinctly staining with Heidenhain's iron haematoxylin. Already at that period, a part of the nuclei become minute, variously deformed, pycnotic and pressed towards the basis of the cell. Homogeneous masses, intensively staining with Heidenhain's haematoxylin, azocarmine or the PAS reaction, begin to appear in the lumina of the glandulae. In places, a fusion of the granules takes place in the cells.

During the peak secretion (partly in October but largely in November), the epithelium of the secretory chambers seems to consist of cells of two types (Fig. 20). A major part of the cells, with distinct, well preserved nuclei, retains its typical structure: their cytoplasm is filled with frequently fusing granulae and also in the lumina of the glandulae there is a homogeneous fused secretion. The remaining cells, mostly with darker and, above all, deformed nuclei, are decreased in size and form loaf-like molds near the basal pellicle of the tubules. The cytoplasm of these cells, feebly staining (light bluish when stained with Azane), lacks in specific granulations. In the course of time, the numbers of light cells increase to the prejudice of the granulated cells but their nuclei do not seem to degenerate. By January the light cells predominate considerably, only individual cells being still granulated. At that period, the lumina of certain glandulae are already free of secretion while the latter is still present in others.

As a rule, the urethral gland resumes its quiescence already by February although it is still enlarged. Within a short period of time, the cells become cylindrical again, their nuclei restoring their original light appearance (Fig. 18). At the same time, droplets of fat appear at their base.

\section{THE FEMALE SEXUAL CYCLE}

Fertilization and formation of vaginal plug

After copulation, a vaginal plug develops in the females of the family Rhinolophidae, discovered by Fries (1879) and described in detail by Rollinat and Trouessart (1897) and Matthews-Harrison (1937). According to these authors, the plug remains in the vagina from the copulation until the fertilization of the ovum and formation of blastocyst. This 

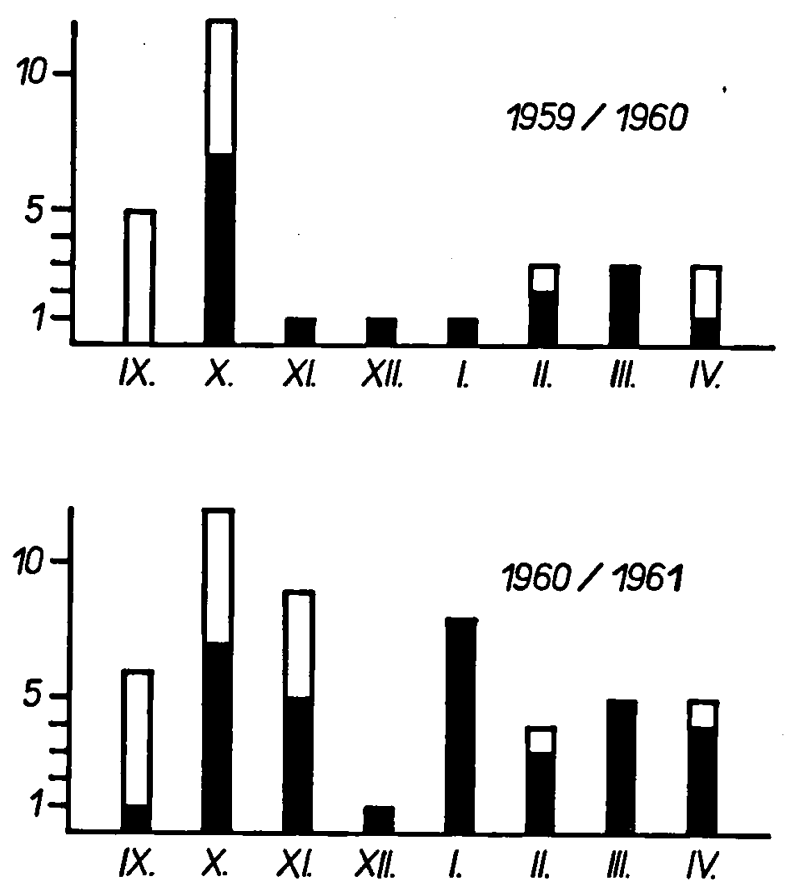

Fig. 22. The incidence of vaginal plug in adult females. Ordinate, number of specimens; abscissa, months; black, females with a plug; white, females without a plug.

fact permits a ready separation of fertilized female R.h. and facilities the study on the course of reproduction.

As seen in Fig. 22, the first females with vaginal plugs were observed in September; the last ones, in April. Save for two females from February, all adult females from December till March were found containing plugs in their vaginae. No vaginal plugs were found in females caught during May and the following summer months. Although neither of the two series (1959/60 and 1960/61) are very numerous, their comparison reveals possible difference of the beginning of the mating season in different years. The earliest fertilized female was observed on 25 September (1960), which confirms the ecological observations according to which $R$.h. copulates mostly as late as in their winter quarters before assuming winter torpidity (GAISLER, 1963a). The latest vaginal plugs were found in two females caught on 30 April (1960) and one female from 26 April (1961). These females already contained distinct corpora lutea in their ovaries. It appears from the findings described above that most of the adult females are fertilized already in autumn, during a period extending from late September till November, and only a small part of them may be fertilized later on during winter or in spring.
Histological examinations of my material complete the observations of the earlier authors on the vaginal plug and the situation of spermatozoa in the female genital tract. The vaginal plug consists of a more or less homogeneous, vitreous matter, oxyphile in staining, which splits in a characteristical way when sectioned (Plate V, Fig. 23). Some of the staining properties of this matter are in accordance with those of the male urethral gland; with Heidenhain's iron haematoxylin, the plug stains intensive black; by the Azane method, intensive reddish orange to dark red; with haematoxylin-eosin, red; it does not stain in the contact haematoxylin method and gives a PAS reaction. Until the ovulation, inactive spermatozoa are kept in the vaginal plug (as shown best by the photomicrographs in the papers by CAFFier and KolBow, 1934, and Sluiter, 1960), in the lumen of the uterus as well as in the uterine glandulae (Fig. 26) and, singly, even in the oviducts. The evidence of ovulation taking place prior to the dissipation of the vaginal plug, described above, confirms the statement by MATTHEWS-HARRISON (1937) that the ovum must be fertilized by some of the spermatozoa kept in the upper part of the female genital tract.

\section{Estrous cycle}

The following is the course of the estrous cycle of the British horseshoe bats according to MatrHEwsHarrison (1937): proestrus, September to October; estrus, end of October; hibernation, November till March; ovulation, first half of April; pregnancy, May, June; lactation anestrus, July, August. However, this distribution does not completely correspond to my findings of vaginal plugs and does not explain the physiological conditions of the females during hibernation. For this reason, I tried to find exact criteria, especially for the duration of the estrus itself, often discussed in bats. Among the organs of the female sexual tract, the changes can be best observed and expressed in the case of the vagina; on these changes, Stockard, Papanicolau and other authors (ex SNELL, 1941) based their classical division of the estrous cycle of rodents into proestrus, estrus, metestrus and diestrus (anestrus). Thus, unlike most authors (with the exception of Caffier and Kolbow, 1934) who devoted their main attention to the study of ovaries in bats, I chiefly examined the vaginae.

The feature characterizing the changes taking place in the vagina of adult female R.h. is, above all, the cornification and desquamation of superficial cells of the vaginal epithelium, commencing in September and culminating in April (Fig. 25). As far as 
the vagina does not contain the plug there are, in its lumen, conspicuous aggregations of cornified cells during that period. Also, the thickness of the entire epithelium varies considerably, being the highest from September till March and the lowest, during summer months. With respect to the thick layer of epithelium, the tunica propria and the muscular coat are conspicuously thin, especially during the period from September till May. During the summer months, when the vagina is generally smaller in size, both these layers are thicker.

The results of measuring the vaginal epithelium (Fig. 32) provide clear evidence of the variation just described. If the process of cornification of the superficial layers of vaginal epithelium is considered a result of estrogen secretion (which has been demonstrated chiefly in rodents, AsDell, 1946), the estrus of the female R.h. may be stated to last from late September till April. One need not be surprised by the observed feeble cornification of the vaginal epithelium during September, as it may be presumed that morphological changes lag behind the beginning of hormonal secretion resulting in the heat.

Matthews-Harrison (1937) already described the microscopical structure of the ovaries in R.h. and its

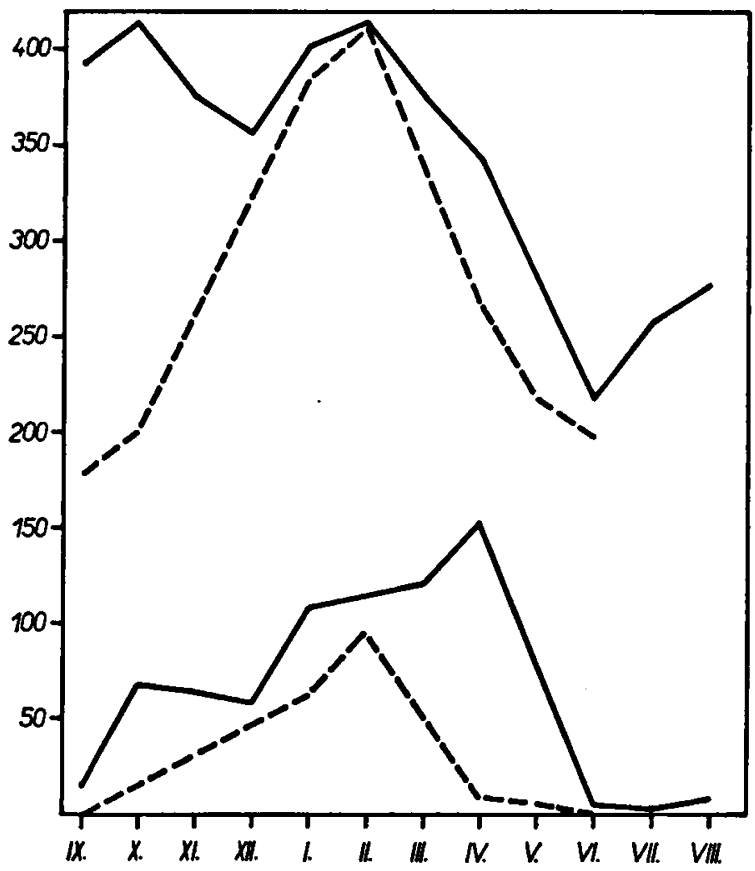

Fig. 32. Variation of thickness of vaginal epithelium during a year. Ordinate, thickness of epithelium, $u ; a b-$ scissa, months; upper part of diagram, thickness of entire epithelium; lower part of diagram, thickness of cornified layer; solid line, adult females; dashed line, grey females. Method of measuring seen in Fig. 25. cyclic changes during the year. Therefore, I refrain from describing the ovaries in such detail as the testes. In my material, the formation of a Graafian follicle, the ovulation and the development of corpus luteum takes place in April, shortly after the end of hibernation (Fig. 29).

I did not succeed to find either tubal ova or blastocysts in my sections but with respect to the presence of the spermatozoa and the vaginal plug in the genital tract of the female R.h., the appearance of corpus luteum may be considered the evidence of their commencing pregnancy. In 1960, I found the first corpus luteum on 30 April and all but one adult females caught in May and June were pregnant (Fig. 33). In that year, I found the first young in central Moravia on 8 July but as late as 28 July, one of the caught females was still pregnant. In 1961, I found the first corpus luteum on 26 April; the first young, on 7 July; and the last pregnant female, on 17 July. From these data, the duration of the gravidity can be calculated as about $2^{1 / 2}$ months. Certainly, the beginning and duration of the gravidity in different years and areas are influenced by the weather and temperature within the shelters, which is a common feature in bats (Eisentraut, 1937, etc.). The duration of the lactation is in accordance with the duration of the postnatal development of the young until attaining the flying capacity, which is 4-5 weeks (GarsLer, 1962). I found the mammary glands being already in involution by the end of August.

Gathering up the above results, the following is the sequence of successive phases of the estrous cycle of reproducing female R.h. in Czechoslovakia: proestrus, late August and early September; estrus, late September till early April; pregnancy, late April till first days of July; lactation, July to early August. Minor deviations from the described course may be expected due to changing weather conditions in successive years.

\section{SEXUAL MATURITY}

Similarly as in the other European bats, three periods can be distinguished in the life cycle of R.h., namely, the juvenile, the subadult and the adult period. The juveniles are the young not yet fully developed; the subadults are fully developed but still sexually immature individuals; and the adults are both fully developed and sexually mature individuals. The juvenile period of R.h. lasts roughly two and a half months, i.e., from July, when the young are born as a rule, till September (Garsler, 1962). However, 


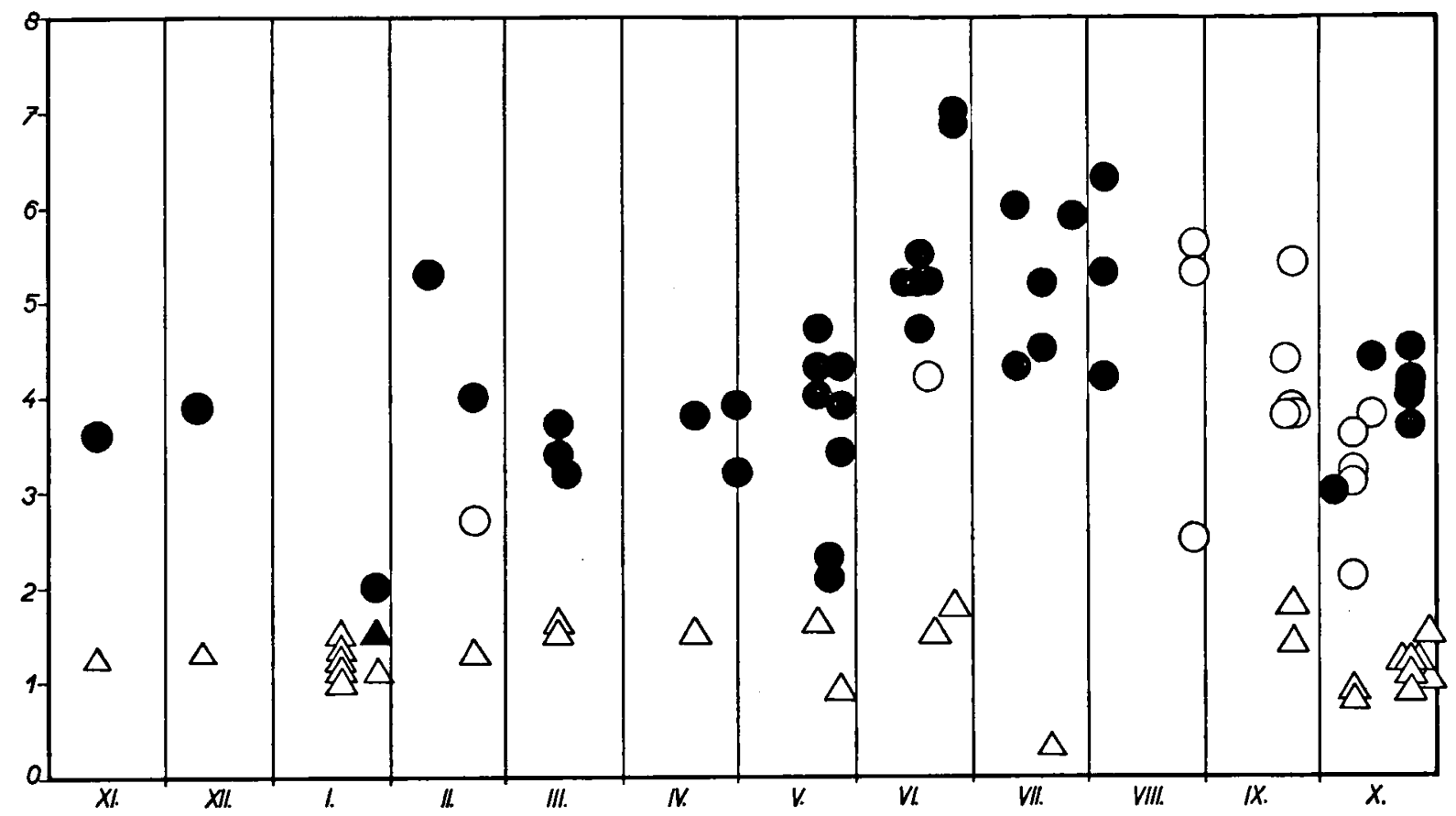

Fig. 33. Participation of females in reproduction during a year. Ordinate, values of $\mathrm{M}$ in mm. (length of pectoral nipples + length of pubic nipples + width of vaginal opening); abscissa, months; rings, brown females; triangles, grey females; solid, females showing signs of participation in reproduction (vaginal plug, pregnancy, lactation).

the separation of the subadult from adult period provides some difficulty with respect to lack of exact age criteria. If we omit the rather numerous literature on the possibility of determining the age of bats by the wear of their teeth (which, anyway, is a rather unreliable criterion in case of bats) we can state that, as a rule, we can exactly separate, in R.h., only individuals younger than one year from those older than one year, according to the colour of their pelage and the appearance of their external genitals. The difference in colour of younger and older individual horseshoe bats was already known to RoLlinat and Trouessart (1897), ANDersen (1917) and certain subsequent authors. As ascertained in a numerous material of R.h. banded in Czechoslovakia, the pelage of individuals younger than some fourteen months of age is grey, that of older ones being greyish brown to brown in colour. Let us see, whether the changes in the pelage colour correspond to the process of sexual maturity.

\section{The male}

During the period October till June, two categories of males are recognizable in the field: one with a thicker penis and a scrotal rudiment well developed (referred to as adults), the other with a thinner penis and the lack of a scrotal rudiment (referred to as subadults). These differences are illustrated in Figs. 34 and 35 (Plate VII). As seen in Fig. 9, the weight of testes of subadult males is distinctly lower than that of adult males in the period from October to May. In June, rapid increase in weight of the testes takes place in both these groups, continuing throughout July, in which month the separation of adult and subadult individuals according to the weight of testes is no more possible. Estimating the age of individuals by the colour of their pelage, one can separate, among the July males, the individuals born in the previous year from the older ones. However, these individuals must be taken for sexually mature according to the appearance of the reproductive organs. Thus one may rightly infer that during July, at the age of about one year, the subadult males attain sexual maturity.

In October to April, the testes of subadult individuals show, in a cross section, an unusually thick tunica albuginea and rather little interstitial tissue. The seminiferous tubules are nearly filled Sertoli cells, with spermatogonia occuring only scarcely. The groups of interstitial cells of Leydig are indistinctly 
developed. The tubules of the epididymides show a similar anatomy as those of the adults but their lumina are narrowed and entirely without spermatozoa. In the subsequent development of testes, the subadult males differ from the adult ones only by a certain retardation of the development in the first months of the warm period (May and June). In July, the microscopic structure of the sexual organs of the males one year of age (still grey) is the same as that of the older (brown) males.

\section{The female}

Similarly as in the males, two categories of the grown-up females are recognizable in the field: one with their pectoral and pubic (anchoring) nipples well developed and the other with their pectoral nipples feebly devloped and without pubic nipples. These differences are illustrated in Figs. 36, 37, 38 and 39. However, one cannot consider these categories referring to adult and subadult females but merely to parous and non-parous animals. The rather complicated problem of separating the sexually immature (or subadult) females from the mature (or adult) ones was first studied on the ground of banded individuals. In these, the colour of their pelage, the size of their pectoral and pubic nipples as well as signs decisive of either juveniles (size, flying capacity, ossification of long bones of wing) or adults (pregnancy, lactation) were recorded. The results are given in Fig. 40.

Only in five cases I succeeded to record further development of females banded as juveniles. Two of these cases indicate that at the age of one year, the females were subadult and did not yet participate in the reproduction. However, the next two cases evidence that females born in July gave birth to their first young already one year later. The last case is merely the evidence of sexual maturity attained by a juvenile female after $3^{1 / 2}$ years.

Additional information is provided by recoveries of 18 females banded when fully grown-up but still grey in colour and with small nipples so that they were tentatively recorded as subadult. The results, together with those of banding juvenile females, confirm, first of all, the above statement, that the grey colouring never lasts longer than one year. Very

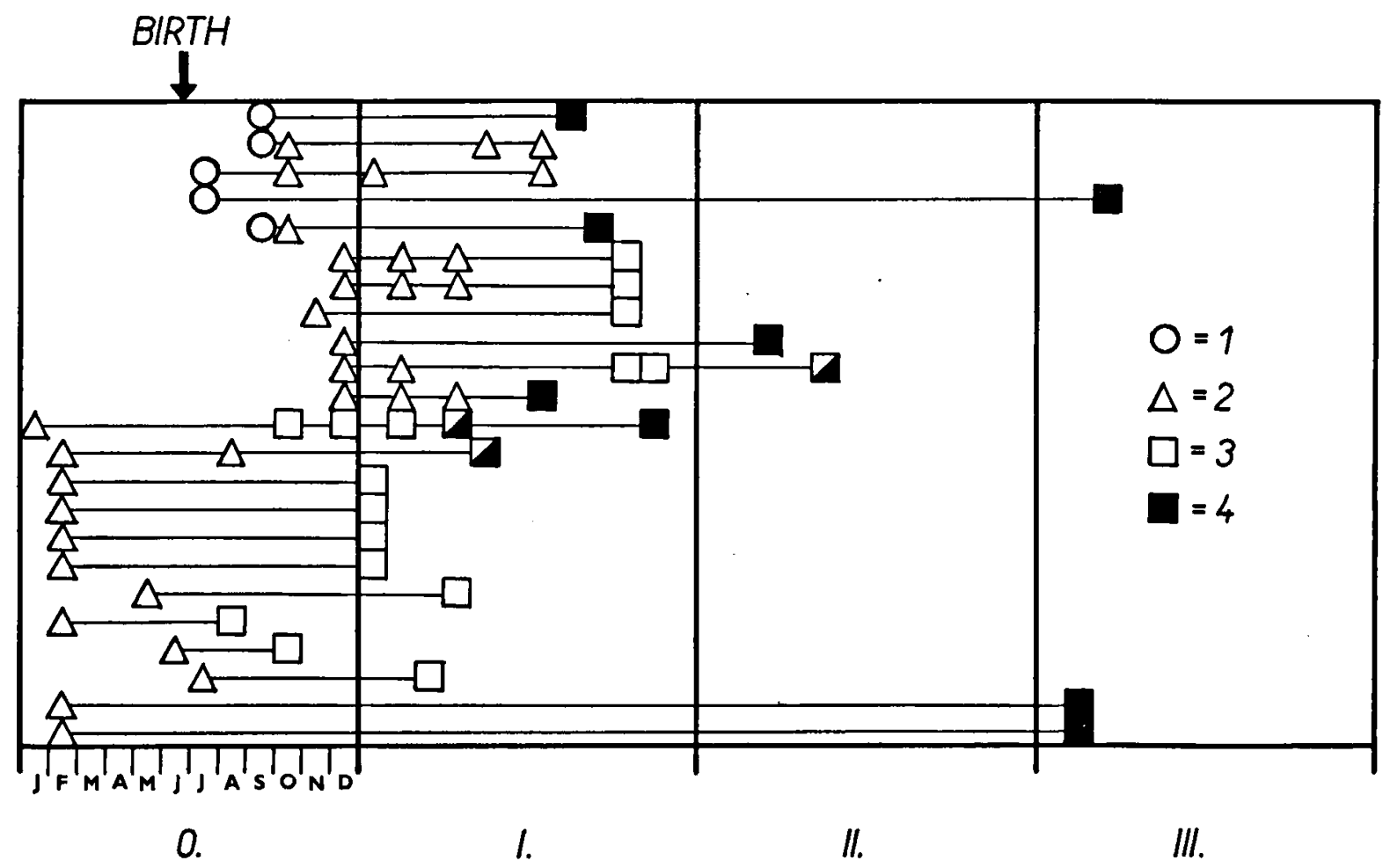

Fig. 40. The recoveries of banded juvenile and grey females, showing the course of sexual maturation. Ordinate, single individuals; abscissa, years and months of banding and recoveries. $O=$ the year of banding, $I=$ the first year after banding, II = the second year after banding, $I I I=$ the third year after banding; $1=$ young, $2=$ grey, $3=$ brown but with still small nipples, $4=$ brown with large nipples. 
likely, in subadult females (or still better yearlings, as termed by e.g. DwYER, 1963), the change in colour takes place sometimes between the end of July and the beginning of September. Thus, brown females are invariably older than one year.

Since the female R.h. produce a single young as a rule, as demonstrated below, "the time at which reproduction first becomes possible, i.e., when germ cells are released" (ASDELL, 1946) may be considered the objective sign of their having attained sexual maturity. It is the time of first ovulation which should take place in April, in analogy with the adult females. Of course, I lack in direct evidence of the first ovulation in the banded individuals; however, there is persuasive indirect evidence of ovulation having taken place, viz., pregnancy and lactation.

Returning now to the material of banded subadult females: first, three individuals must be excluded from further evaluation as they do not provide any information on sexual maturity (I keep on commenting upon Fig. 40). Of the remaining females, only one produced a young in the year subsequent to her birth as she was parous during the winter to follow, according to the condition of her nipples. Summing up the evaluable material of females banded as juveniles and subadults, making up 19 cases, there are 3 (or 15.8\%) cases of attaining sexual maturity at the age of less than one year, and 16 (or 84.2\%) cases in which no reproduction had taken place at the age of one year. The banding results do not indicate whether the females of the second group at the age of less than one year ovulated but were not fertilized or did not ovulate at all.

Further evidence on sexual maturation is derived from the material investigated in morphological respect. As shown in Fig. 33, all individuals of this material were classified according to values obtained by summing up the length of both pectoral nipples, both pubic nipples and the width of the vaginal opening (the resulting value being denoted as $M$ ). It appears from Fig. 33 that the grey females younger than one year show the lowest values of $M$. The only evidence of sexual activity among the members of this group is the finding of a vaginal plug in one distinctly grey female caught in January. Besides, Fig. 33 includes 6 females already showing brownish colour but with low values of $M<3$. These females are non-parous but three of them show signs of participation in the reproduction: they either show a vaginal plug or are pregnant.

Of the sexual organs of the grey females, attention is paid again to their vagina and ovary. Their vagina is much smaller than that of the adult females but of much the same structure (Fig. 24). Cornification of the superficial layers of the vaginal epithelium was observed in all 10 grey females from October till February whose vaginae were examined histologically. As seen in Fig. 32, this cornification commences in October and culminates during winter; during April, when the cornified layers are thickest in adult females, they are thin again in the grey ones. It is inferred from this observation that the secretion of estrogen takes place already in females 4 to 8 months of age although it is very likely lower than in females older than one year. Thus, the physiological condition of these young females is close to estrus and some of them copulate, as evidenced by the finding of a vaginal plug in January (Fig. 33). Nevertheless, I consider females of this age sexually immature. It should be noted that the capability of estrogen production by immature gonads of mammals has been proved (Young, 1961).

I could follow the development of the ovary already from a young still incapable of flying, captured on $27 \mathrm{July,} 1960$. The ovary of this female contained only the primary follicles. In the ovaries of subadult females, I found, apart from the primary follicles, also growing follicles in September. In the subsequent months, the condition of the ovary remained practically unchanged (Fig. 30). The ovary of a grey female from April (Fig. 31) also contained only primary and growing follicles without antra and did not show the least signs of a preparation for ovulation, in which it differed markedly from the microscopical condition of the ovary of a mature female from that period (Fig. 29). Unfortunately, I only could examine the April condition of the ovary of a single grey female that obviously had not been fertilized. Basing on the above-described observation, I must presume that the ovulation takes place in a smaller part of the grey females, that is, that certain females ovulate before having attained the age of one year. To find out why some of the females younger than one year can ovulate and others cannot, and whether there is a possible influence of the presence of spermatozoa in their genital tract will require further investigation. For completeness' sake, I would like to remark that even during the subsequent months of May and June, the ovaries of grey females investigated did not show any increased activity.

Summing up the results of both methods of investigation, that is, the ecological and the morphological one, one arrives at the following conclusion: While the first signs of estrus appear in female R.h. already 
at the age of 4 months, most of them attain sexual maturity only at the end of the second year of their life. A small number of females (some $15 \%$ according to banding results) reproduce already at the end of their first year of life, very likely having attained sexual maturity at the age of 10 months.

\section{NOTES ON POPULATION DYNAMICS}

The ecological factors governing the population density and dynamics of R.h. in Czechoslovakia were described in my previous papers (GAISLER, 1963a, b). The character of shelters of this species in Czechoslovakia, especially its winter quarters in central Moravia (extensive caves in the Karst area) where I carried out most of my investigations, does not permit to obtain data suitable for a statistical evaluation of its population density, mortality and survival rates and other important element of its population dynamics. In this respect, I would like to draw the reader's attention to a similar study by BEzEM, Sluiter and van HeErdt (1960) though in different parts of the area of R.h., the relations may be slightly different. In this chapter, I shall concentrate on conclusions on population dynamics of $R$.h. resulting from the investigations on its reproduction. They are concerned with litter size, number of reproducing females and sex ratio.

The litter size was ascertained by dissecting 46 pregnant females (most of this additional material was collected for the purpose of investigations on ontogenesis and has not been included in the number of 149 individuals given in Methods) or from the observations of females with young up to one week of age, clinging to their mother's body; the total of these females was 52 . Of the pregnant females, 45 contained one embryo each in their uteri; one female caught on 21 May, 1959, contained two embryos. This discovery is the first direct evidence of the possibility of development of two embryos in this species (Fig. 27). However, the possibility of subsequent resorption of the smaller embryo is not excluded. All 52 females caught with young had one young each. Thus, the litter size of a great majority of female R.h. in Czechoslovakia is one young; a production of twins has not been proved."

The number of reproducing females younger than one year is small, making up some $15 \%$ of the mem-

- Prof. Dr. H. Frick (Frankfurt a.M.) kindly informed me on a find of two fetuses in a female R.h. shortly before parturition. Unfortunately, the material had been used up for purposes of the anatomical institute and the particulars were no more detectable. bers of this age class according to the results given above. However, even some females older than one year do not reproduce, that is, they do not produce young each year. I calculated the percentage of reproducing females older than one year from a total of 164 brown females, mostly banded, recovered in June, July and August. I determined by weighing whether a particular female was pregnant and according to the condition of her nipples, I could readily determine whether lactation was taking or had taken place. 153 (or 93.3\%) of these females reproduced, 11 (or 6.7\%) did not reproduce. Of the latter group, 6 females (or 54.5\%) were still non-parous while 5 females (or $45.5 \%$ ) were parous. Very likely, the percentage of adult not reproducing females varies in successive years, in differrent populations or even in different summer colonies.

The sex ratio was determined separately for juvenile, subadult and adult individuals. Again, the calculations are based on a material of mostly banded individuals. While the entire material was used for the calculation of sex ratio among the young, the calculations of sex ratio among the grown-ups, subadults and adults involved only the material from winter quarters, to avoid bias that could be introduced by substantial difference in habitat requirements of males and females during summer (GAISLER, 1963a). Therefore, the sex ratio among the subadults and adults was calculated from material collected from November till March when the samples obtained reflect comparatively well the actual relations in the population.

The results are tabulated in Tab. 1. My material is the first sample enabling the evaluation of sex ratio among the juvenile $R . h$. This ratio does not significantly differ from the ideal ratio of $50 \%$ of males: $50 \%$ of females, or $1: 1$. Thus, we may consider the males and the females to be equally frequent among the young in the population.

Further, the material of subadults and adults was classified according to the habitats, based on my earlier observations (GArsLen, 1963a). The results thus obtained indicate a predominance of females in winter quarters in buildings (cellars) and that of males in winter quarters other than buildings (caves and galleries). I attempted to explain this feature in my paper mentioned above and will not repeat it here. However, it is worthwhile to note that the predominance of subadult females in buildings is statistically insignificant and that of adult females approaches the level of significance, while the predominance of males in the material from caves and galleries is 
Table 1. Sex ratio among the Czechoslovakian populations of R.h. (see text)

\begin{tabular}{|l|c|c|c|c|}
\hline \multicolumn{1}{|c|}{ Age class } & $\mathrm{n}$ & $\%$ & $\chi^{2}$ & $\mathrm{P}$ \\
\hline Juveniles & 234 & 52.1 & 0.42 & $>0.5$ \\
Subadults from buildings & 108 & 55.5 & 1.33 & $>0.2$ \\
Subadults from caves + galleries & 670 & 44.0 & 9.54 & $<0.01$ \\
Total of subadults & 778 & 45.6 & 5.94 & $<0.02$ \\
Adults from buildings & 225 & 56.0 & 3.24 & $<0.1$ \\
Adults from caves + galleries & 1103 & 27.4 & 22.57 & $<0.01$ \\
Total of adults & 1328 & 32.2 & 16.77 & $<0.01$ \\
Total, adults and subadults & 2106 & 37.2 & 13.85 & $<0.01$ \\
& & & & \\
\hline
\end{tabular}

significant for both subadults and adults. This may be partly due to greater material from winter quarters other than buildings. However, it must be stressed that even the difference between the percentages of adult males and females in winter quarters other than buildings is substantially greater than in the material from buildings. Even when presuming that under our conditions, equal numbers of R.h. hibernate in buildings and in caves incl. galleries, the average percentage of subadult females would be $49.7 \%$, that of adult females, $41.7 \%$. Thus, adult males would predominate even in that case. The actual numbers of both these components (bats hibernating inside and outside the buildings) cannot be determined. Theoretically, one may assume that the component hibernating in buildings is more numerous. In Czechoslovakia, R.h. is a hemisynanthropic species (GaISLER, 1963b), finding a sufficient number of satisfactory shelters in buildings all over its area even during winter. Certainly, caves and galleries are generally more satisfactory winter quarters due to their spaciousness and suitable microclimatic conditions; however, they are concentrated in only certain areas and in places remote from human habitations as a rule. In this respect, they attract bats from a wider environment. Thence, it is my opinion that the more vagrant component may predominate in the winter population of the caves, consisting, in the case of R.h., of adult males (HaNák, Gaisler and Frgala, 1962).

\section{DISCUSSION}

The male sexual cycle

The spermatogenesis of adult male R.h. begins in the spring after the termination of winter torpidity, attaining its peak towards the end of July and in
August and ending in the autumn before the beginning of winter torpidity. This course of spermatogenesis is substantially the same as in several species of the family Vespertilionidae, studied in this respect so far (Courrier, 1927; Miller, 1939; Pearson, Koford and Pearson, 1952; Sluiter, 1961). Very likely, similar relations hold true for adult males of all bats of the Temperate Zone.

Although the spermatogenous activity of the epithelium of the seminiferous tubules ends towards the autumn, the males are capable of fertilizing throughout the winter and perhaps even in spring as at that time, the tubules of the epididymides are filled with spermatozoa. Also, the accessory glands show a considerable activity during the autumn and winter period. Grulich (verbal communication) observed copulation in R.h. at the beginning of April, 1949, in Mladečské jeskyně Cave which evidences sexual activity of the males even in early spring. The problem of hormonal regulation of male sexual activity of bats of the Temperate Zone in the period from autumn till spring has not yet been clarified. Pearson, Koforn and Pearson (1952) looked for the source of androgens in the interstitial cells of the testes. However, the histochemical reactions used by these authors to prove the secretory activity of these cells were negative. On the other hand, Courrier (1927) comments on the interstitial cells as follows: "Pendant la période de rut nous avons toujours trouvé, chez tous les sujets examinés, les cellules interstitielles volumineuses, munies d'un gros noyau, riches en cytoplasme, ce cytoplasme est creusé de nombreuses vacuoles qui sont la trace d'une graisse labile ...". This corresponds to the above described observations on the interstitial cells of Leydig of male R.h. in the period from October to April. Vignoli (1930). who studied the testes in Rhinolophus ferrumequinum. 
likewise stated that "I lipoidi si accumulano in quantità singolare negli elementi interstiziali durante i] riposo spermatogenetico ...". More recently, this problem was reviewed by WIMSATT (1960), who points out "the possibility that small but effective quantities of androgen produced during the period of breeding activity preceding hibernation might persist in the testes or elsewhere, e.g. in brown fat ....". In reality, Krutzsch and Welss (1960) brought evidence of the presence of an androgenic substance in the interscapular brown fat obtained from the American bat Myotis lucifugus during the hibernation season.

A special remark is due to the urethral gland on which RoBIN (1881b) comments as follows: "Il existe dans le genre Rhinolophe une glande spéciale, la glande uréthrale, qui semble représenter morphologiquement des glandes de Littre conglomérées et qui présente une structure histologique analogue à celle des glandes de Cowper et joue probablement le même rôle physiologique". Branca (1904) described the secretory activity of the cells of this gland which he denotes as mixed merocrinous and holocrinous. In our observations, the gland is at the peak secretion in October and November. With respect to the fact that the stainability of the secretion of this gland is in full accordance with that of the female vaginal plug we can corroborate the hypothesis of MatThews-Harrison (1937) that the vaginal plug consists mostly of the secretion of the urethral gland. Very likely, the secretion of prostate and perhaps even of seminal vesicles takes part in the formation of the vaginal plug as well, as known in other mammals (ENGLE, 1926). However, one must refuse the older views on the formation of vaginal plug from the vaginal secretion (Rollinat and Trouessart, 1897) or the desquamated vaginal epithelium (CAFFier and Kolbow, 1934).

\section{The female sexual cycle}

The results of investigations on female reproductive organs of R.h.hipposideros in Czechoslovakia are in substantial agreement with those obtained by MATTHEWS-HARRISON (1937) in R.h.minutus. Like this author, I could prove that ovulation takes place prior to the dissipation of the vaginal plug preventing subsequent copulations, which is a clear evidence of a separated copulation and fertilization of ovum. Judging the mating period from the described findings of vaginal plugs it can be said that copulation takes place from late September till November; thus, it begins somewhat earlier than in R.h.minutus. Later on, during winter months or in spring, copulation in $R . h$. are scarce in this country. In this respect, our populations of $\boldsymbol{R} . \boldsymbol{h}$. differ from the North American and northern European populations of certain species of the family Vespertilionidae in which copulations are equally or more frequent during winter and spring than in autumn (Guthrie, 1933, Strelkov, 1962).

In spite of the mentioned difference in the mating season, the female sexual organs, namely the ovaries, of all European and North American bat species studied so far show a very similar cycle of seasonal changes (with but one exception in Miniopterus schreibersi, Courrier, 1927, Dwyer, 1963, etc.). Thus it may be expected that even the estrous cycle of females of these species will be much the same. However, in literature, one meets with two quite contrary interpretations of the course of estrus in females of bats of the Temperate Zone.

Most of the authors accept the opinion of RoBIN (1881a) and some other earlier authors, corroborated later on chiefly by CAFFier and Kolbow (1934), that the estrus lasts from autumn till spring, being a result of adaptation to life in periodically cooled regions. According to certain North American authors (Guthrie and Jeffers, 1938; Reeder, 1939; WimSATT, 1944), the female bat is in a "subestrous" condition during the winter sleep. Important results were brought by the investigations on a correlation between marked seasonal changes in pituitary cytology and the annual cycle of reproduction in the female bat Myotis myotis, carried out by Herlant (1953, 1956, 1958). His magnificent study demonstrated that the anterior hypophysis contains five distinct types of chromophilic cells and produced some indirect evidence which suggests that $\mathrm{LH}$ may be the specific ovulating hormon in the bat, being normally produced only after the end of hibernation, or in bats prematurely aroused. I cannot discuss the details (see reviews in the paper by WIMSATT, 1960 and the monograph by Young, 1961) but only will mention that HerLant, too, is of the opinion that "ces animaux sont normalement en oestrus permanent au cours de l'hiver ...".

On the contrary, Scrwab (1952) points out that in mammals, the neurohumoral stimuli, inducing the estrus, are always temporarily connected with ovulation or with that phase of development of the follicles which immediately precedes ovulation. ScHwaB believes that a part of the females during autumn and winter copulations is a quite passive one and ascribes “die Duldung des Besamung ohne Brunst ... einer 
bestimmten Reflexwirkung ...". Pearson, Koford and Pearson (1952) observed frequent copulations of active males with inactive females in Corynorhinus rafinesquei. All females, both adult and subadult, are fertilized before the end of November but copulations continue even during winter. Thus, the authors are also inclined to believe that the part of the females in copulation is more or less passive and that no such estrus takes place as known in most of the remaining mammals. In this connection they state that “... at no time does the vaginal epithelium reach the condition typical of oestrus in many rodents". And further on, "Sections of the vagina in fall, winter, and spring show a deeply stratified epithelium, but no true cornification". However, their otherwise excellent paper contains no photomicrographs of those sections.

The relations described in R.h. in the previous chapters correspond to the first conception. First of all, copulations take place mainly in autumn, at the period when both sexes are still active at nights. My direct observations on certain unusual behaviour of flying R.h. at that period (epigamic display) suggest that the part played by the females is not only passive. The decisive evidence of estrus is that of the condition of vaginal epithelium which, in R.h., shows conspicuous cornification of superficial layers from October till April. This phenomenon was already mentioned by CAFFIER and Kolbow (1934) and observed in hibernating females of certain species of the genus Myotis by Guthrie, Belcher and Castelnuovo (1941), Sluiter and Bouman (1951) and Herlant (1953).

There is an important paper by WrMsatr (1960) who reviewed the problems of reproduction in relation to hibernation in bats. He rightly infers, that "it appears unlikely that the immediate factors controlling reproductive phenomena in bats differ in fundamental quality from those operative in other mammals, for the reproductive organs of bats respond in the same ways to gonadotrophic and sex hormones". The exceptional prolongation of estrus is certainly in some connection with the hibemation. There remains a more less academical question whether in the species populating the Temperate Zones of Asia, Europe and America (or their ancestors), the estrus took place in autumn (EISENTraut, 1937 ) or in spring (Pearson, Koford and Pearson, 1952; Herlant, 1953). Thus, though I would not generalize my results as valid for the remaining species of bats of the Temperate Zone, I take it for probable that the females of all these species pass a period of estrus like other mammals.

\section{Sexual maturity}

It is generally believed that the European bats attain sexual maturity during the second year of their life (Eisentraut, 1937; Kuzyaxin, 1950; Bels, 1952). This is corroborated in males by the results of SLurter (1961) in Myotis myotis and by my own observations in R.h. Till the spring, the testes of male R.h. younger than one year are entirely immature and inactive, showing no signs of spermatogenesis. The tubules of the epididymides are free from spermatozoa. The sex accessories are very small in size. These males attain sexual maturity at the age of approximately 12 to 14 months so that, according to all appearances, they are first capable of fertilizing in the second autumn of their life.

However, there are some different observations on the time at which males of European and American bats become sexually mature. Thus, according to Courrier (1927), the males of the family Vespertilionidae attain their sexual maturity as late as during the third year of their life; according to MILLER (1939), the males of two North American Myotis species attain sexual maturity during the second year of their life; according to Pearson, Koford and Pearson (1952), the testes of male Corynorhinus rafinesquei show a certain spermatogenous activity already at the age of four months, however "it is unlikely that young males copulate in their first year"; and according to SHORT (1961), the males of Tadarida brasiliensis mexicana seem to be sexually mature at the age of about 18 to 22 months. The observations do not agree in the family Rhinolophidae either. According to Vignoli (1930), "Gli animali impuberi e di egual taglia, catturati alla fine di agosto, presentano, a seconda degli individui, testicoli di tipo grande e di tipo piccolo". Divale (1964) comments on the same species Rhinolophus ferrumequinum as follows: "most males can fecundate at the age of 3 years and some months; the balance, one year later". On the contrary, Isssex (1950) observed that $R . h$. of both sexes are "im 2. Herbst ihres Lebens geschlechtsreif".

Before I shall attempt to explain these differences, I will discuss the sexual maturity of females. In them, still greater disagreements exist. The evidence of reproducing female R.h. younger than one year described above indicates that some of them must have ovulated and attained sexual maturity prior to reaching one year of age. Also, SLurter (1960) observed in R.h. in the Netherlands that "some females of the first-year-class give birth at the end of their first year, others do not". SLuirer arrived at his conclusion by an indirect statistical method which is 
quite different from that applied by myself. In his opinion, reproducing females of the first-year-class are fertilized only after the termination of winter torpidity. However, my observation of a grey female with a vaginal plug in January indicates that these females may be fertilized earlier, perhaps even during the first autumn of their life.

These observations do not quite agree with those of some earlier authors on the time in which female R.h. attain sexual maturity. According to Rollinat and Trouessart (1897), most of the females remain virgin until the third autumn of their life; according to Matrhews-Harrison (1937), they do not reproduce during the first year of their life "and are at least fifteen months old at the first oestrus". According to Dinale (1964), in Rhinolophus ferrumequium "... quite surely no female litters at the age of 2 years; certainly a part of females litters for the first time at the age of 3 years; another part one year later; it is possible that a small percentage of females litters for the first time at the age of 5 years" (1). On the other hand, copulating females younger than one year are not at all scarce among the bats of the Temperate Zone. Similar cases are known among certain North American Vespertilionidae (Guthrie, 1933; Pearson, Koford and Pearson, 1952). Sluiter and Bouman (1951) quite clearly showed the cornification of the vaginal epithelium in hibernating immature female Myotis myotis. These authors concluded that "young females of Myotis myotis and Myotis emarginatus as a rule become oestrous and are indeed inseminated in the autumn, which follows after their birth in June, notwithstanding the fact that they will not reach sexual maturity before the next summer". Nevertheless, females of Myotis myotis, Myotis emarginatus and Myotis mystacinus (SLUTter, 1954; give birth for the first time when they are two years old.

There are three possible explanations of the differences between the observed times of sexual maturity in both males and females of different European and North American bat species: (1) The time of reaching sexual maturity is different in different species. (2) The time of reaching sexual maturity is different in different populations of the same species, possibly due to the influence of local ecological conditions. (3) It is not excluded that lack of exact age criteria introduced certain bias into the conclusions of some of the authors. It is difficult to judge the last mentioned possibility; however, I believe that most of the differences are real. It is a striking fact that most of the observations on reaching sexual maturity at re- latively high age were made in southern countries such as southern France (Courrier, 1927), Italy (Dinale, 1964), etc. On the contrary, western and central European bats do not, for the first time, reproduce later than at the age of two years. However, the observations on North American bats contradict, to some extent, this conception. At all events, one must take into account the possible differences between the species, subspecies or even populations. Most species of bats of the Temperate Zone seem to attain sexual maturity sometimes during the second year of their life. I do consider the reproduction at the end of the first year of life, as observed in a small part of female R.h. in Czechoslovakia and the Netherlarids, exceptional.

\section{Population dynamics}

Female R.h. give birth to one young a year. While the reports of certain earlier authors (RYBERG, 1947), the mathematical conclusions of the paper by SLuITER (1960) and the above described two findings of two embryos suggest the possibility of a birth of twins, direct evidence of it is still missing. The greatest longevity determined by banding is $14 \frac{1}{2}$ years (HERREI, 1964). In Czechoslovakia, I recovered one male 10 years and one female, 9 years after banding; according to the banding date, these individuals were at least $10 \frac{1}{2}$, or $9 \frac{1 / 2}{2}$ years old, resp. Bezem, SLuiter and van HeErdt (1960) calculated the adult survival rate of 0.567 years and the mean longevity of 2.3 years in a population of R.h. in South Limburg.

Of the numerous reports on sex ratio in R.h., my results can be compared with those obtained by Mrkos and Trummer (1951) who found, in the caves of Lower Austria, $28.3 \%$ of females $(n=1,919)$, and with those obtained by Bezem, SLuiter and vaN HEERDT (1960) who found $46.8 \%$ of females ( $\mathrm{n}=$ $1,717)$ in the caves of South Limburg. The latter authors explain the predominance of males in the similar way as I do, viz., by different habitat requirements of adults of different sex.

On the ground of a confrontation of morphological investigations on 24 females from January with the capture-recapture data, Suviter (1960) concluded on population dynamics of R.h. in South Limburg. Of his conclusions, I already mentioned those on reproduction of certain females younger than one year and births of twins to be expected to occur in $35 \%$ of females. Besides, SuUtrer believes all two-years-old and older females to reproduce. However, my material from the summer season indicates that in our population of R.h., a minor part of adult females do 
not give birth and that even in the parous females, single individuals do not reproduce in a particular year.

Thus it appears that the reproduction potential of our populations of R.h. is low and that a rapid increase in numbers can by no means be expected under incidental exceptionally favourable conditions. In conclusion, I may state that, with respect to the relations among the central European bats, the population density of $R . h$. in the study area is rather high and is not decreasing during the recent years.

\section{SUMMARY}

The present paper gathers the results of a morphological study on 149 specimens of Rhinolophus hipposideros, and of ecological investigations on additional material, incl. some 5,000 banded individuals of the same species.

Brief description of the reproductive organs of both sexes is given. The reproductive organs of the sexually mature (adult) and the sexually immature grown-up (subadult) individuals are illustrated and comments are made on their changes during the year.

In adult males, the spermatogenesis commences in spring, after the change from winter torpidity to active life, and culminates towards the end of July and in August. During the winter months (December to April), the seminiferous epithelium of the tubules of testes is resting. On the contrary, the interstitial cells of Leydig are conspicuously developed in the period from October to April (or May). The tubules of the epididymides of adult males are never entirely free of spermatozoa but they contain the lowest numbers of the latter at the period of intensive spermatogenesis. Towards the end of August and in September, the tubules of the cauda epididymidis begin to be filled with greater numbers of spermatozoa, being overcrowded with them in the period from October till April. Apart from the ampullar glands, the seminal vesicles, the prostate and the bulbourethral or Cowper's glands, the males of R.h. possess a conspicuously developed accessorv sexual gland. discovered. in Rhinolophus, by RoBIN (1881b) and termed the glandula urethralis. This gland is the greatest element of the male genital tract, being at the peak of its secretory activity in October and November. The staining properties of the secretion of this gland indicate that the urethral gland takes an im- portant part in the origin of the female vaginal plug.

Most of the adult females were found to copulate already in autumn, from late September till November. Ovulation takes place in April, still before the dissipation of the vaginal plug. Pregnancy lasts for about $2 \frac{1}{2}$ months; lactation, for 4 to 5 weeks. The main information on the course of estrous cycle was obtained by histological examinations of vaginal epithelium. The following is the succession of the individual phases of the estrous cycle of reproducing female R.h. in Czechoslovakia: proestrus, late August and early September; estrus, late September till early April; pregnancy, late April till first days of July; lactation, July and early August.

The life of R.h. can be divided into three main periods, viz., the juvenile, subadult and adult period. The juvenile period lasts about two and a half months, from July till September. The pelage of individuals younger than some 14 months of age is grey, that of older ones being greyish brown to brown in colour. The male R.h. attain sexual maturity at an approximative age of one year and are first capable of fertilizing at the age of about 15 months, in the second autumn of their life. While the first signs of estrus appear in female R.h. already at the age of 4 months, most of them attain sexual maturity only towards the end of the second year of their life. A small percentage of females (15\%, according to banding results) reproduce already at the end of the first year of their life.

Although the uterus of one pregnant female $R . h$. was found to contain two embryos, our results indicate that the litter size equals one. The greatest longevity of R.h. in Czechoslovakia, determined by banding, is $10^{1 / 2}$ years for males and $9 \frac{1}{2}$ years for females. A certain percentage of adult females (6.7\% of the material examined) do not reproduce. Sex ratio among the juveniles is $1: 1$ while males predominate among the subadults and, especially, adults; however, a question arises of the extent in which the sample obtained corresponds to the actual relations in the population.

The paper is concluded by a discussion. The main problems arising from the study are discussed, viz., the possible hormonal regulation of the male sexual activity, the estrous condition of females, especially during hibernation (the so-called "subestrus"), and the time of attaining sexual maturity. 


\section{REFERENCES}

ANDERSEN, K., 1917: On the so-called colour phases of the rufous horseshoe-bat of India (Rhinolophus rouxi, Temm.). Journ. Bombay Nat. Hist. Soc. 25, 260-273.

ASDELL, S. A., 1946: Patterns of mammalian reproduction. Ithaca, N.Y.

BELS, L., 1952: Fifteen years of bat banding in the Netherlands. Publ. Natuurh. Genootsch. Limburg 5, 1-99.

BezeM, J. J., J. W. Sluiter and P. F. van Heerdt, 1960: Population statistics of five species of the bat genus Myotis and one of the genus Rhinolophus hibernating in the caves of S. Limburg. Arch. Néerl. de Zool. 13, 511-539.

BranCA, A., 1904: Le cycle sécrétoire de la glande uréthrale des Chéiroptères. Note préliminaire. ComptesRendus Ass. Anat. Bibl. Anat. 13, 66-72.

Caffier, P. und H. Kolbow, 1934: Anatomisch-physiologische Genitalstudien an Fledermäusen zur Klärung der therapeutischen Sexualhormonwirkung. Zeitschr. Geburtsh. und Gynäkol. 108, 185-235.

Courrier, R., 1927: Etude sur le déterminisme des caractères sexuels secondaires chez quelques mammifères à l'activité testiculaire périodique. Arch. de Biol. 37, 173-334.

Dinale, G., 1964: Studi sui Chirotteri italiani II: Il raggiungimento della maturità sessuale in Rhinolophus ferrum equinum Schreber. Atti Soc. Ital. Sc. Nat. e del Mus. Civ. St. Nat. Milano 103, 141-153.

DWYER, P. D., 1963: The breeding biology of Miniopterus schreibersi blepotis (Temminck) (Chiroptera) in northeastern New South Wales. Australian Jour. Zool. 11, 219-240.

Eisentraut, M., 1937: Die deutschen Fledermäuse. Leipzig.

ENGLE, E. T., 1926: The copulation plug and the accessory genital glands of mammals. Journ. Mammalogy 7, 119-126.

FrIES, S., 1879: Uber die Fortpflanzung der einheimischen Fledermäuse (Chiropteren). Zool. Anz. 2, 355357.

Gaisler, J., 1962: Postnatale Entwicklung der Kleinen Hufeisennase (Rhinolophus hipposideros Bechst.) unter natürlichen Bedingungen. Symposium theriologicum, Brno, 1960, 118-125.

- 1963a: The ecology of lesser horseshoe bat (Rhinolophus hipposideros hipposideros Bechstein, 1800) in Czechoslovakia, I. Acta Soc. zool. Bohemoslov. 27, 211-233.

- 1963b: The ecology of lesser horseshoe bat (Rhinolophus hipposideros hipposideros Bechstein, 1800) in Czechoslovakia, II: Ecological demands, problem of synanthropy. Acta Soc. zool. Bohemoslov. 27, 322-327.

- 1965: The female sexual cycle and reproduction in the lesser horseshoe bat (Rhinolophus hipposideros hipposideros Bechstein, 1800). Acta Soc. Zool. Bohemoslov. 29, 336-352.

Gaisler, J. and M. Titlbach, 1964: The male sexual cycle in the lesser horseshoe bat (Rhinolophus hipposideros hipposideros Bechstein, 1800). Acta Soc. zool. Bohemoslov. 28, 268-277.
Grassé, P. P., 1955: Traité de zoologie, XVII. Mammifères, 2. Paris.

Guthrie, M. J., 1933: The reproductive cycles of some cave bats. Journ. Mammalogy 14, 199-216.

Guthrie, M. J., J. C. Belcher and G. Castelnuovo, 1941: Differentiation of the reproductive tract in female bats (Myotis grisescens) and the question of the source of estrogenic hormone. Anat. Rec. 79 suppl. 2, 28-29.

GUTHRIE, M. J. and K. R. JEFFERS, 1938: A cytological study of the ovaries of the bats Myotis lucifugus lucifugus and Myotis grisescens. Journ. Morphology 62 . 523-557.

Hanák, V., J. Gaisler and J. Figala, 1962: Results of bat-banding in Czechoslovakia, 1948-1960. Acta Univ. Carolinae - Biol., Praha, 1962: 9-87.

Herlant, M., 1953: Etude comparative sur l'activité génitale des Chiroptères. Ann. Soc. zool. Belg. 84, 87116.

- 1956: Corrélations hypophyso-génitales chez la femelle de la chauve-souris, Myotis myotis (Borkhausen). Arch. Biol. 67, 89-180.

- 1958: Corrélations hypophyso-génitales chez la femelle des chauves-souris. Bull. Soc. zool. de France 83, 337357.

Herreid II, C. F., 1964: Bat longevity and metabolic rate. Experimental gerontology 1, 1-9.

ISSEL, W., 1950: Okologische Untersuchungen an der Kleinen Hufeisennase (Rhinolophus hipposideros Bechstein) in mittleren Rheinland und unteren Altmühltal. Zool. Jahrb., Syst. Ökol. Geogr., 79, 71-86.

Krutzsch, P. H. and W. W. Wells, 1960: Androgenic activity in the interscapular brown adipose tissue of the male hibernating bat (Myotis lucifugus). Proc. Soc. Exp. Biol. and Medic. 105, 578-581.

Kuzyakin, A. P., 1950: Bats. Moscow. (In Russian)

Matthews-Harrison, L., 1937: The female sexual cycle in the British horseshoe bats. Trans. zool. Soc. London 23, 224-266.

MILlER, R. E., 1939: The reproductive cycle in male bats of the species Myotis lucifugus and Myotis grisescens. Journ. Morphology 64, 267-295.

Mrkos, H. und H. TrimmeL, 1951: Das Zahlenverhältnis Männchen: Weibchen bei Mausohr und Hufeisennase. Die Höhle, Wien, 2, 22-25.

Pearson, O. P., M. R. Koford and A. K. Pearson, 1952 Reproduction of the lump-nosed bat (Corynorhinus rafinesquei) in California. Journ. Mammalogy 33, 273320.

ReEder, E. M., 1939: Cytology of the reproductive tract of the female bat, Myotis lucifugus. Journ. Morphology 64, 431-453.

Robin, H. A., 1881a: Sur l'époque de l'accouplement des chauves-souris. Bull. Soc. philomath. Paris 7, 5: 88-94.

- 1881b: Recherches anatomiques sur les mammifères de l'ordre des Chiroptères. Libraire Acad. Médec., Paris, A 45 (469).

Rollinat, R. et E. Trouessart, 1897: Sur la reproduction des chauves-souris, II: Les Rhinolophes et note 
sur leurs parasites épizoïques. Mém. Soc. zool. de France 10, 114-138.

RYBerG, O., 1947: Studies on bats and bat parasites. Stockholm.

SchwaB, H., 1952: Beobachtungen über die Begattung und die Spermakonservierung in den Geschlechtsorganen bei weiblichen Fledermäusen. Zeitschr. mikr.anat. Forschung 58, 326-357.

SHORT, H. L., 1961: Age at sexual maturity of Mexican free-tailed bats. Journ. Mammalogy 42, 533-536.

Sluiter, J. W., 1954: Sexual maturity in bats of the genus Myotis, II: Females of $M$. mystacinus and supplementary data of female $M$. myotis and $M$. emarginatus. Proc. Kon. Ned. Akad. Wet. Amsterdam 57, 695-700.

- 1960: Reproductive rate of the bat Rhinolophus hipposideros. Proc. Kon. Ned. Akad. Wet. Amsterdam 63, 383-393.

- 1961: Sexual maturity in males of the bat Myotis myotis. Proc. Kon. Ned. Akad. Wet. Amsterdam 64, 243-249.

Sluiter, J. W. and M. Bouman, 1951: Sexual maturity in bats of the genus Myotis, I: Size and histology of the reproductive organs during hibernation in connection with age and wear of the teeth in female Myotis myotis and Myotis emarginatus. Proc. Kon. Ned. Akad. Wet. Amsterdam 54, 594-601.

SNELL, G. D., 1956: Biology of the laboratory mouse. New York.
STrelkov, P. P., 1962: The pecularities of reproduction in bats (Vespertilionidae) near the northern border of their distribution. Symposium theriologicum, Brno, 1960, 306-311.

VAmburKar, S. A., 1958: The male genital tract of the India megachiropteran bat Cynopterus sphinx gangeticus And. Proc. Zool. Soc. London 130, 57-77.

VIGNOLI, L., 1930: Il testicolo di Rhinolophus ferrum equinum nella sua maturazione sessuale e nelle sue variazioni cicliche annuali. Arch. Ital. Anat. Embr. 28, 103-132.

WIMSATT, W. A., 1944: Growth of the ovarian follicle and ovulation in Myotis lucifugus. Amer. Journ. Anat. 74, 129-173.

- 1960: Some problems of reproduction in relation to hibernation in bats. Bull. Mus. Comp. Zool. 124, 249270.

Wolf, J., 1954: Microscopical technique. Praha. (In Czech)

Wood-Jones, F., 1917: Genitalia of Chiroptera. Journ. Anat. 51, 36-117.

Young, W. C., 1961: Sex and internal secretions, I, II. Baltimore.

Author's address: Dr. Jiří Gaisler, Institute of Vertebrate Zoology, Czechoslovak Academy of Sciences, Brno, Drobného 28, Czechoslovakia. 
PLATES 


\section{PLATE I}

Fig. 1. Ventral view of the adult male reproductive organs. $\quad 4 \times$. Fig. 2. Dorsal view of the adult male reproductive organs. $4 \times$.

Fig. 3. Ventral view of the subadult male reproductive organs in situ. $4 \times$. Fig. 4. The urethral gland of an adult (left) and subadult (right) male. $11 \times$. $1=$ testes, $2=$ epididymides, $3=$ ductus deferentes, $4=$ glandulae ampulares, $5=$ glandulae vesiculosae, $6=$ vesica urinaria, $7=$ glandula urethralis, $8=$ glandulae bulbourethrales, $9=$ penis, $10=$ prostate, $11=$ sinus urogenitalis (with a part of urethra masculina), $12=$ musculus bulbocavernosus.

All photographs relate to specimens collected in February. Photo: V. Hrabè.

\section{PLATE II}

Fig. 5. Ventral view of the adult female reproductive organs.

Fig. 6. Dorsal view of the adult female reproductive organs.

Fig. 7. Ventral view of the subadult female reproductive organs.

Fig. 8. Dorsal view of the subadult female reproductive organs.

$1=$ right ovarium, $2=$ left ovarium, $3=$ body of the uterus, $4=$ right horn of the uterus, $5=$ left horn of the uterus, $6=$ vesica urinaria, $7=$ vagina. $\quad$ All $6 \times$. All photographs relate to specimens collected in February. Photo: V. Hrabè.

\section{PLATE III}

Testis cycle of adult males.

All $200 \times$. Fig. 10. May. Staining: Heidenhain's iron haematoxylin. Fig. 11. Beginning of July. Azane.

Fig. 12. End of July. Heidenhain's iron haematoxylin. Spermatogenesis at its peak, islets of interstitial cells are small.

Fig. 13. October. Heidenhain's iron haematoxylin. End of spermatogenesis, distinct signs of degenerating sexual cells. Fig. 14. November. Azane. Conspicuous islets of interstitial cells.

Fig. 15. April. Haematoxylin - oleic red. Interstitial cells in mighty continuous stripes.

\section{PLATE IV}

Ductus epididymidis of adult males. $250 \times$. Fig. 16. November. Azane. Terminal segment filled with spermatozoa.

Fig. 17. May. Heidenhain's iron haematoxylin. Middle segment with single spermatozoa.

Sex accessories of adult males. All $200 \times$. (Fig. 21, photo: O. Vašír ).

Fig. 18. Glandula urethralis. February. Haematoxylin oleic red. End of secretory activity.

Fig. 19. Glandula urethralis. April. Haematoxylin - oleic red. Resting stage.

Fig. 20. Glandula urethralis. November. Azane. Peak of secretory activity.

Fig. 21. Seminal vesicle, filled with secretion. March. Haematoxylin - eosin.

\section{PLATE V}

Fig. 23. Vaginal plug. November. Haematoxylin - eosin.

$100 \times$.

Fig. 24. Vagina of a subadult female, with desquamuting superficial layers of epithelium. January. Azane. $50 \times$. Fig. 25. Close-up of vaginal epithelium with desquamating cornified layers. Adult female without vaginal plug. November. Method of measuring of (1) thickness of vaginal epithelium, (2) thickness of cornified layer. Haematoxylin - eosin.

$120 \times$.

Fig. 26. Spermatozoa in uterus and uterine glands of a fertilized female (see arrows). January. Haematoxylin eosin.

$250 \times$.

Fig. 27. Two embryos and a placenta in the uterus of $a$ pregnant female. May. Heidenhain's iron haematoxylin.

$40 \times$

\section{PLATE VI}

Fig. 28. Largest follicle in the right ovary of adult female, taken from hibernation. February. Haematoxylin - eosin. $200 \times$

Fig. 29. Corpus luteum graviditatis from the right ovary of adult female. April. Haematoxylin - oleic red. $200 \times$. Fig. 30. Ovary of a subadult female. January. Haematoxylin - eosin.

$120 \times$.

Fig. 31. Ovary of a subadult female, showing no signs of preparations for ovulation. April. Haematoxylin - eosin. $120 \times$.

\section{PLATE VII}

Fig. 34. The external genitalia of adult male; note the appearance of scrotum (or better scrotal rudiment).

Fig. 35. The external genitalia of subadult male without scrotal rudiment.

Fig. 36. The external genitalia of adult female; note the presence of anchoring nipples.

Fig. 37. The external genitalia of subadult female without anchoring nipples.

Fig. 38. The pectoral nipple of an adult female.

Fig. 39. The pectoral nipple of a subadult female.

All photographs relate to specimens collected in February. Photo: V. Hrabè. 


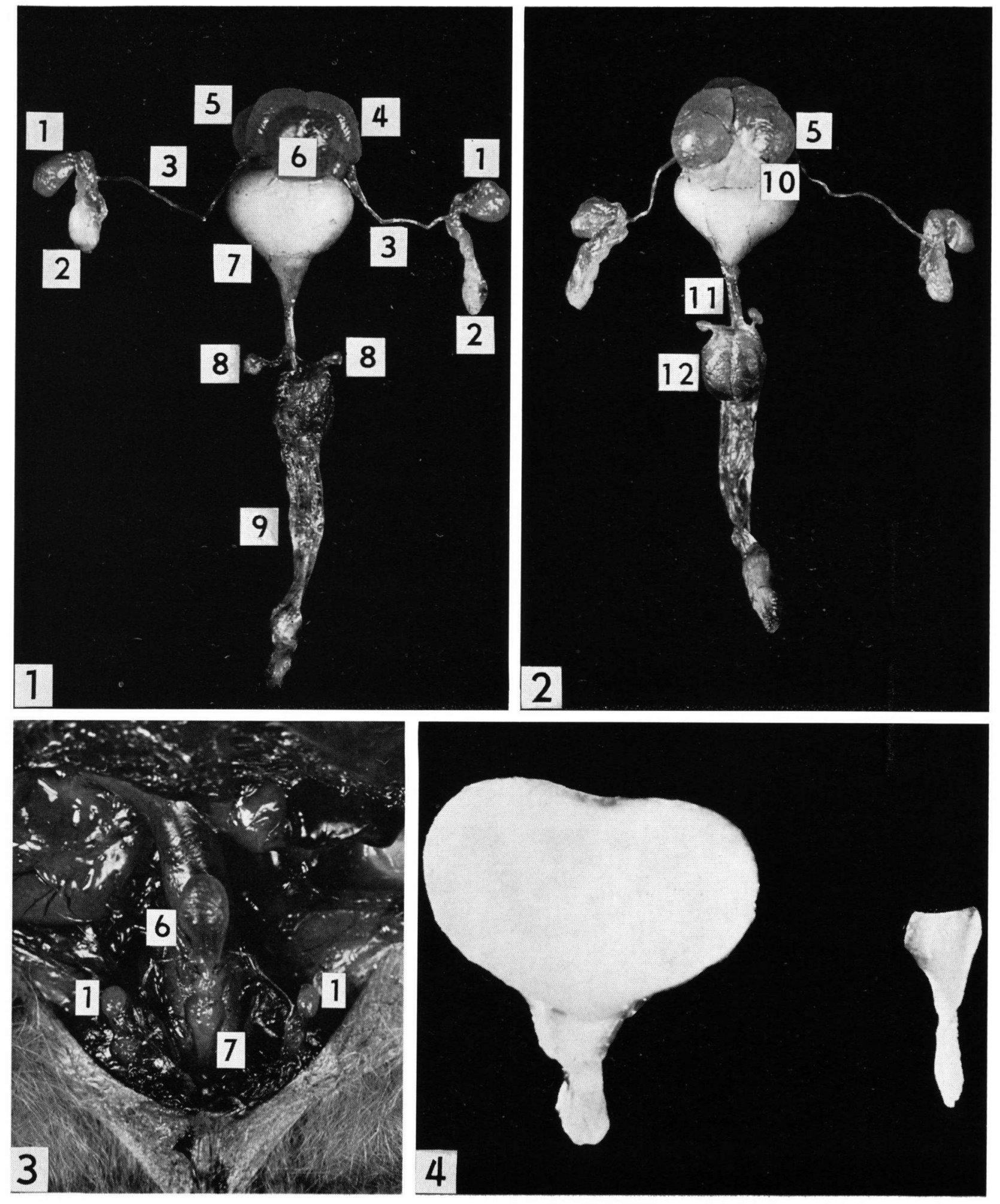

PLATE 1 

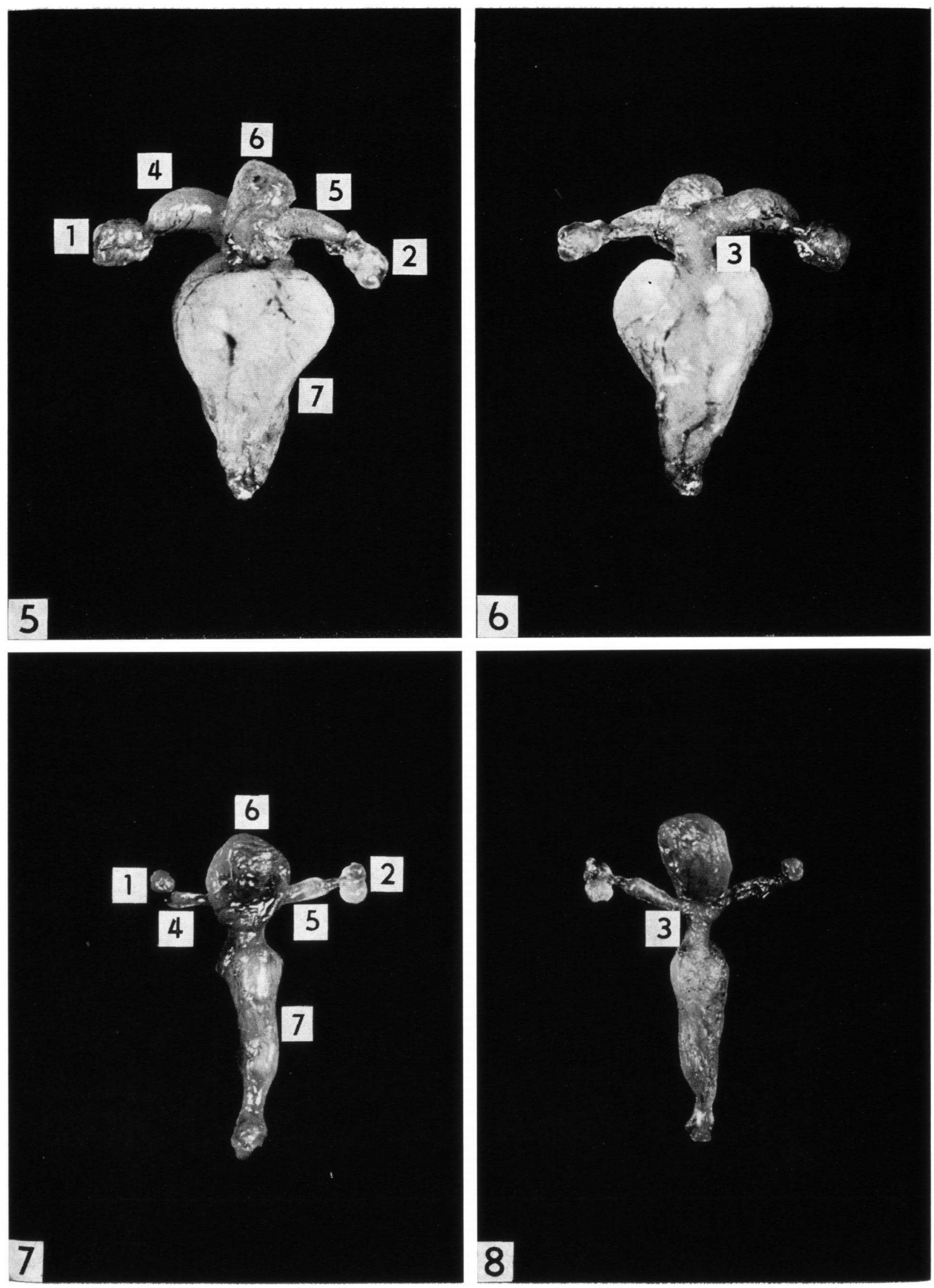

PLATE II 

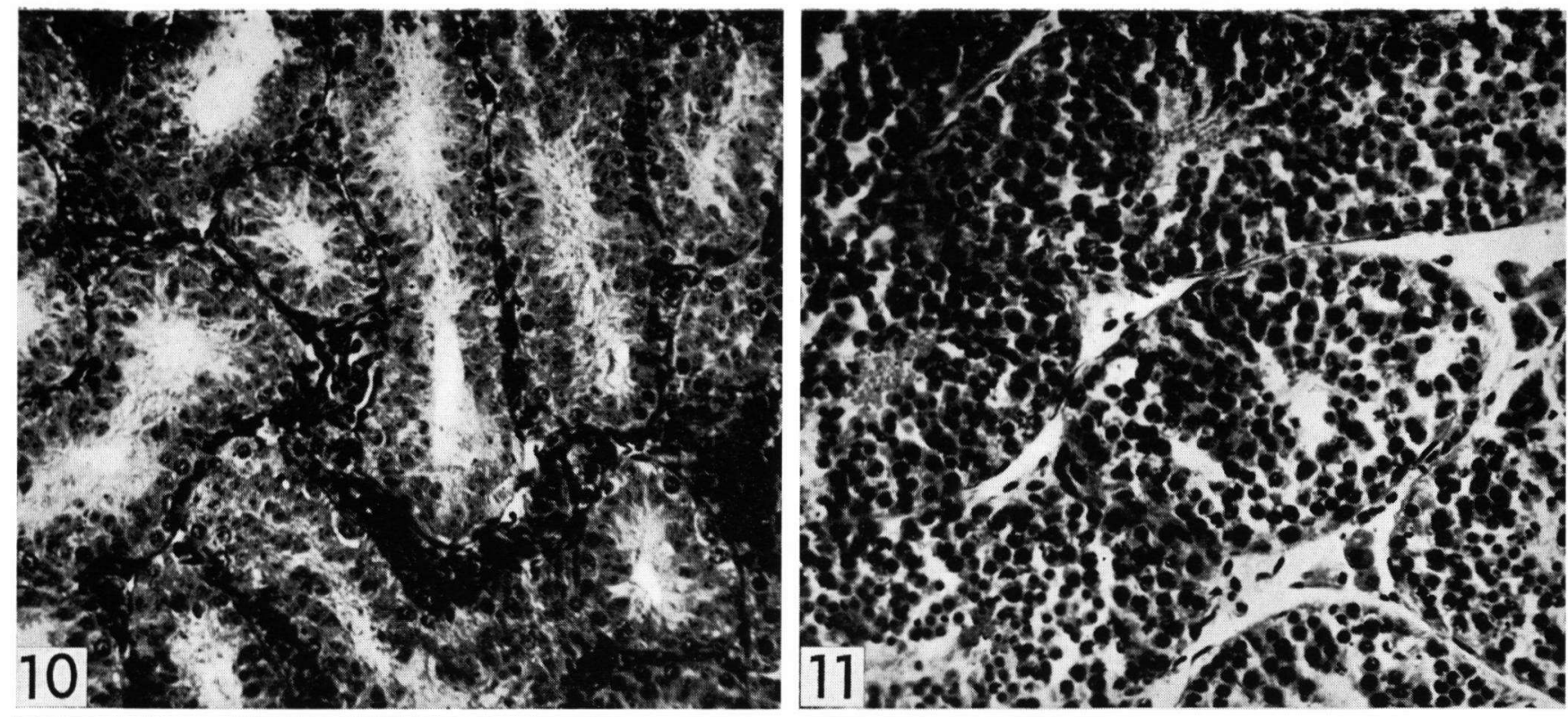

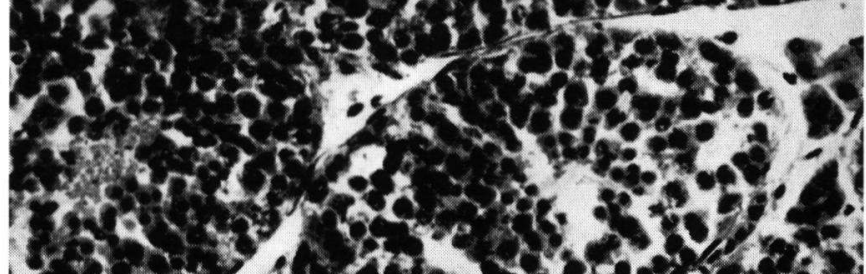

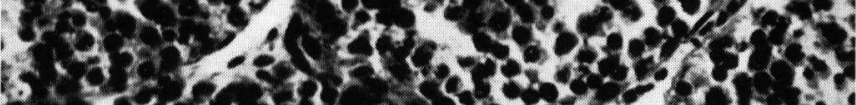

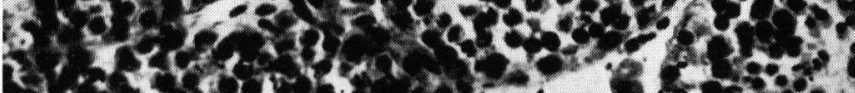

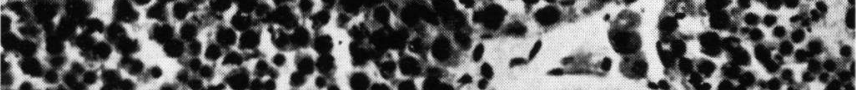

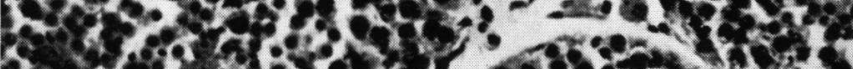
- 4 or 0 rotos

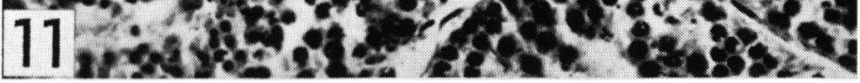
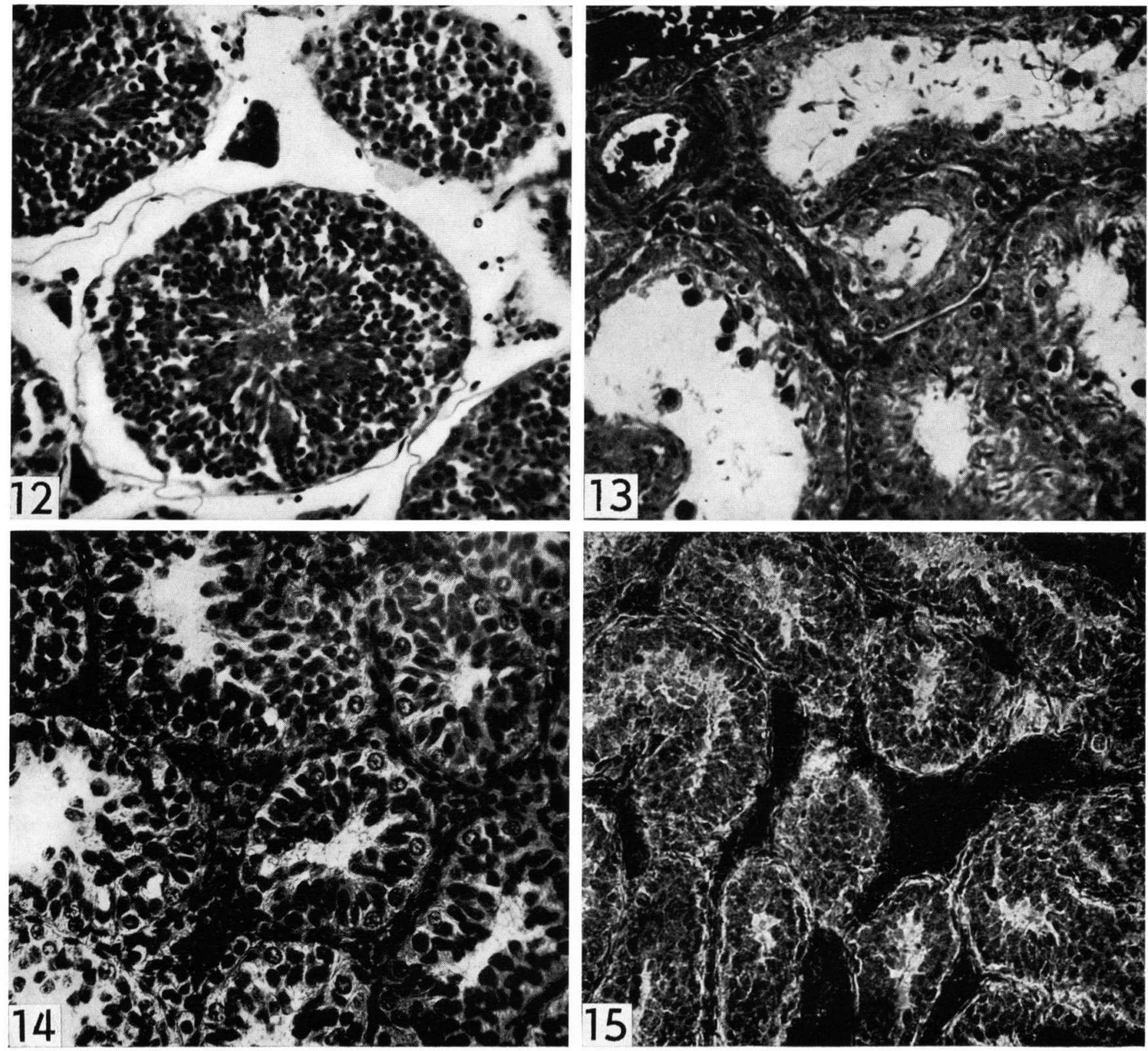


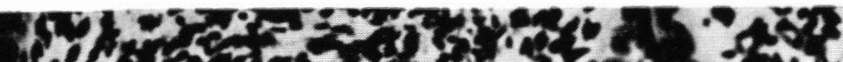
Aly (1)

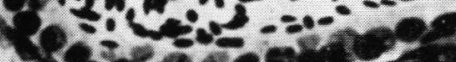

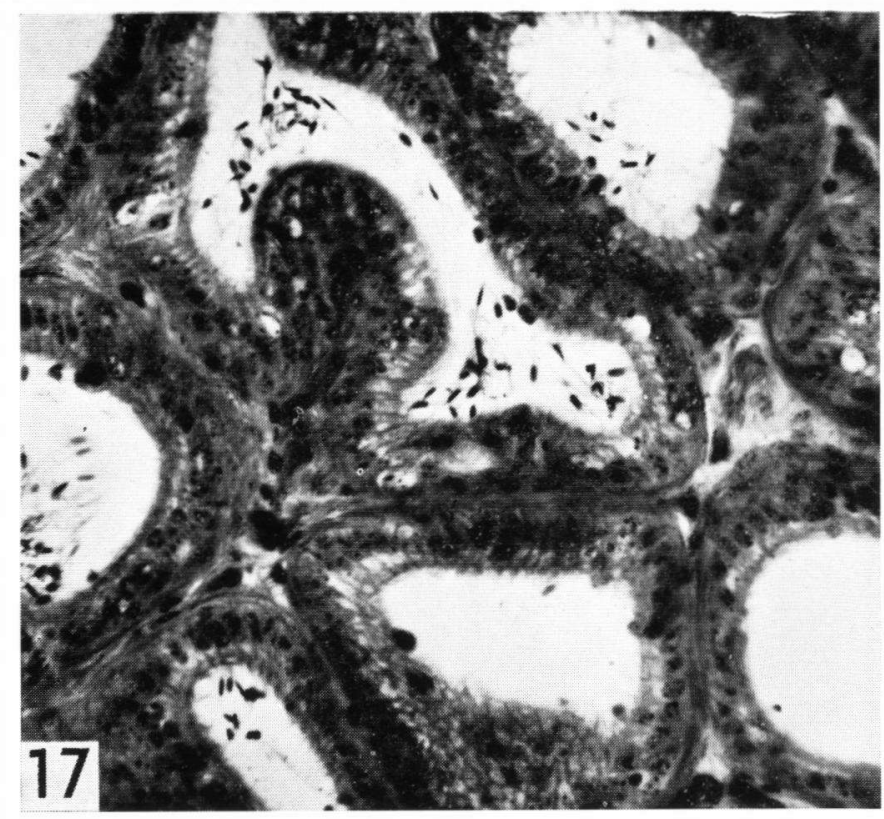

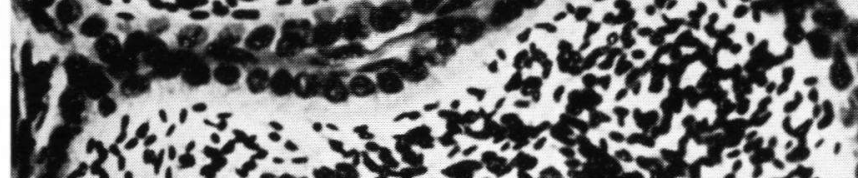
1 r.

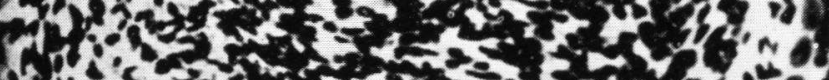
(4.

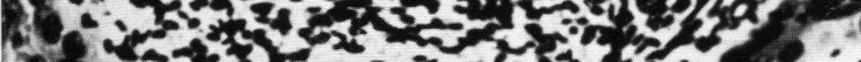

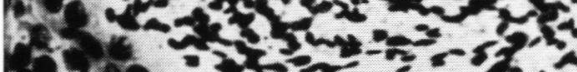

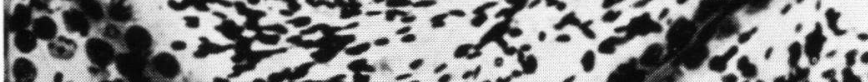
5 b. $16 \mathrm{~kg}$. $16 \mathrm{k}$.
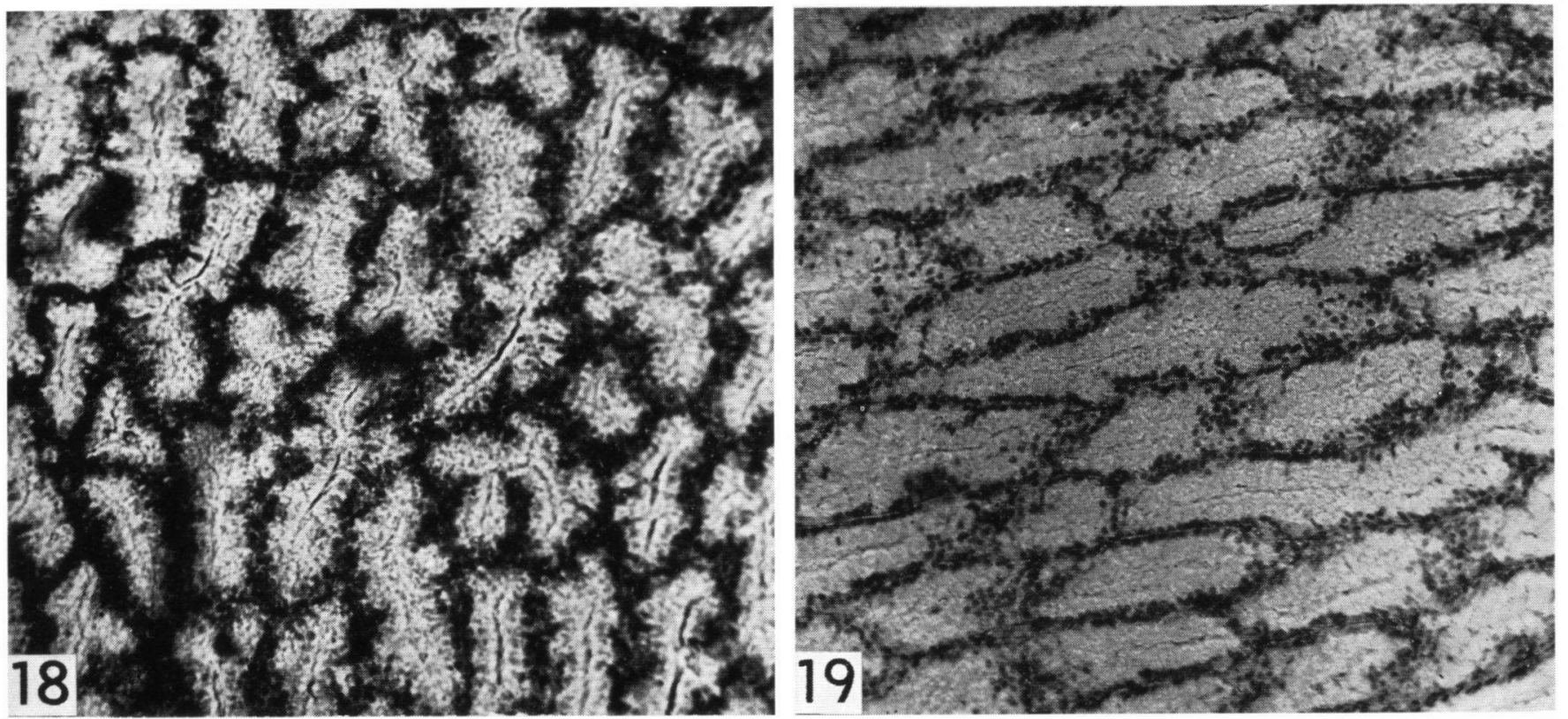

5. Ha

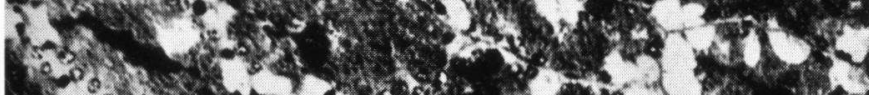
3.

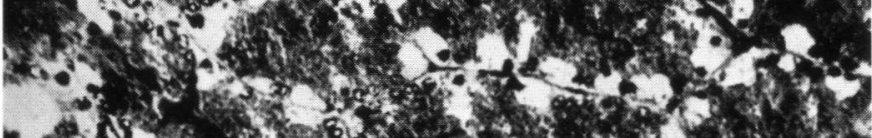

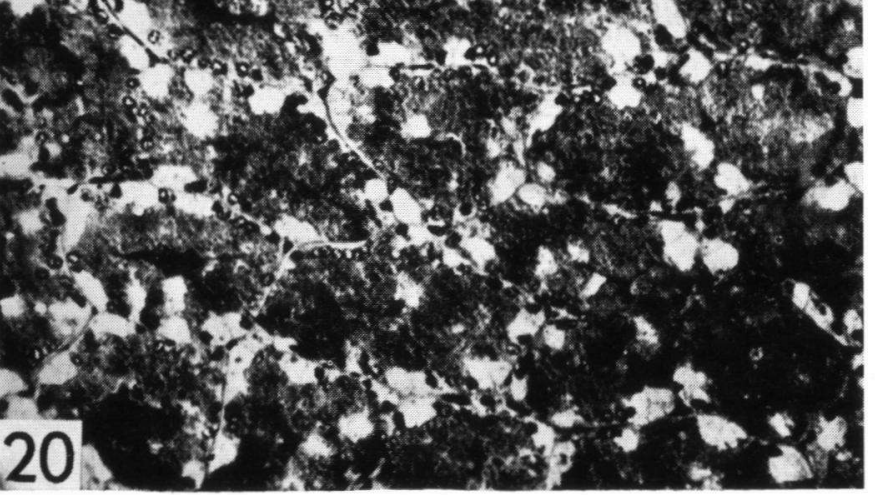

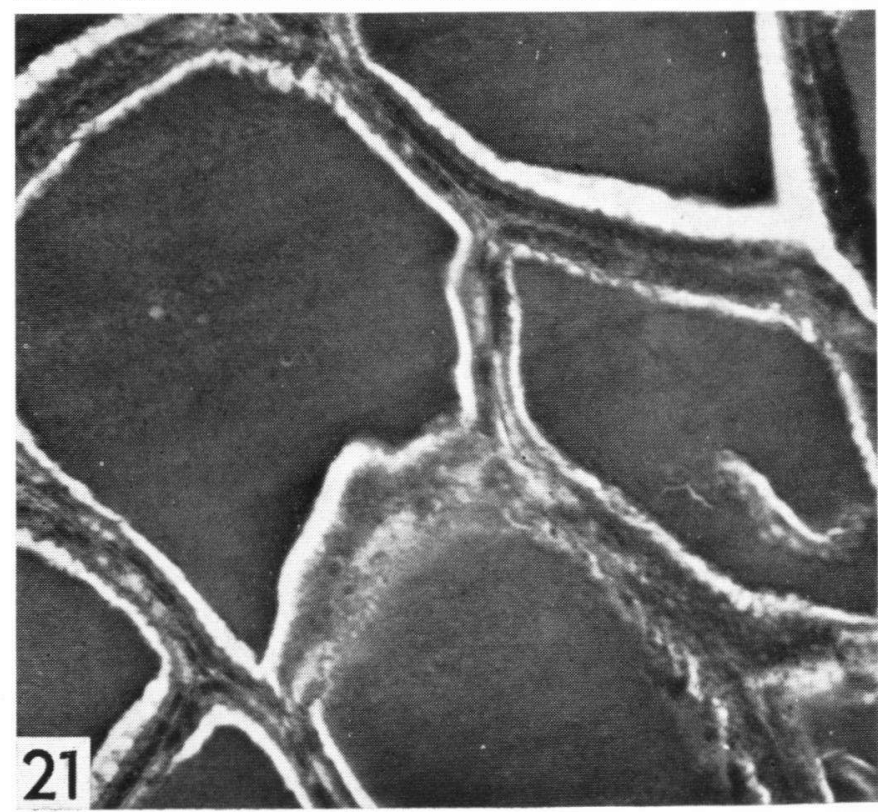



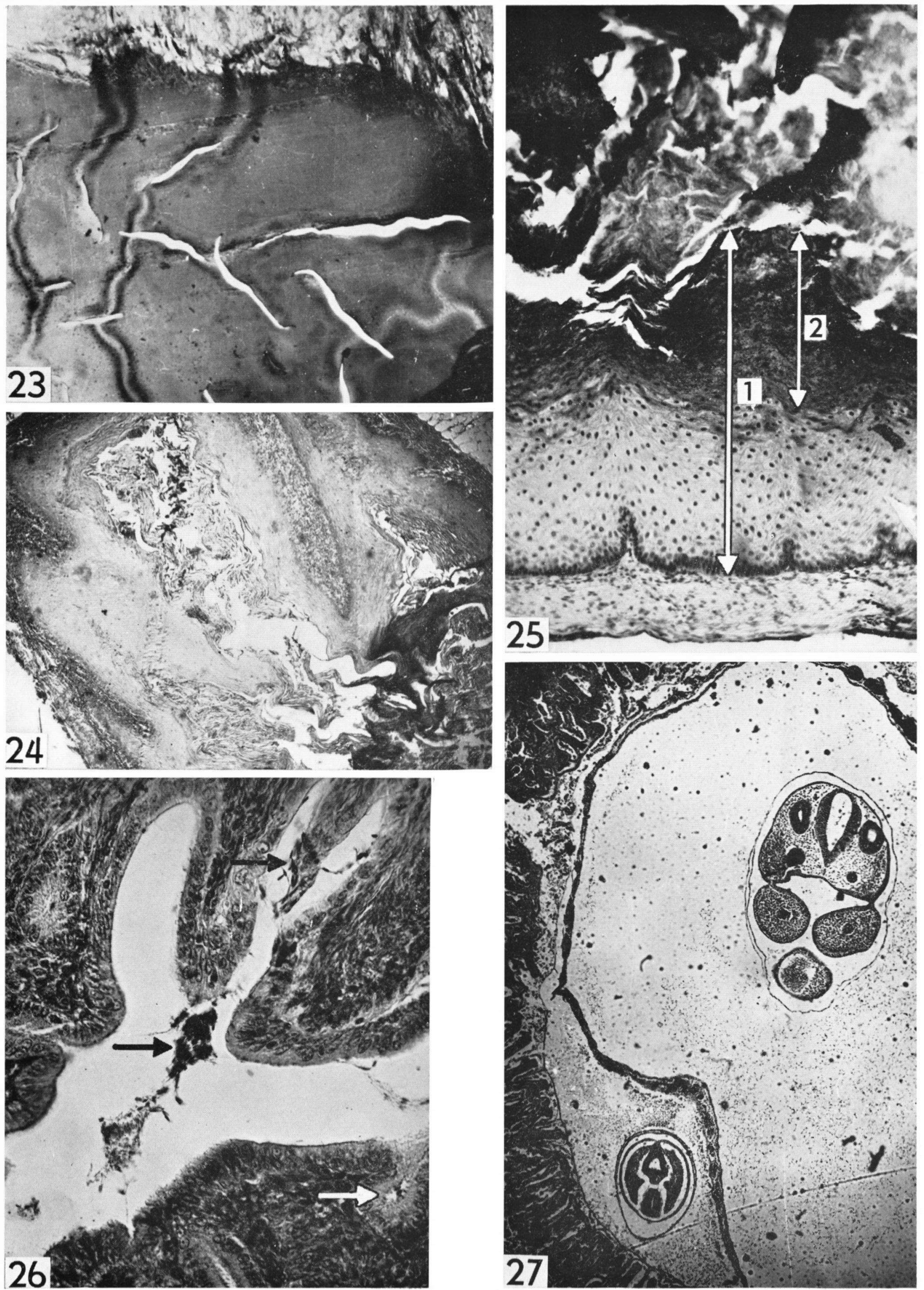

,

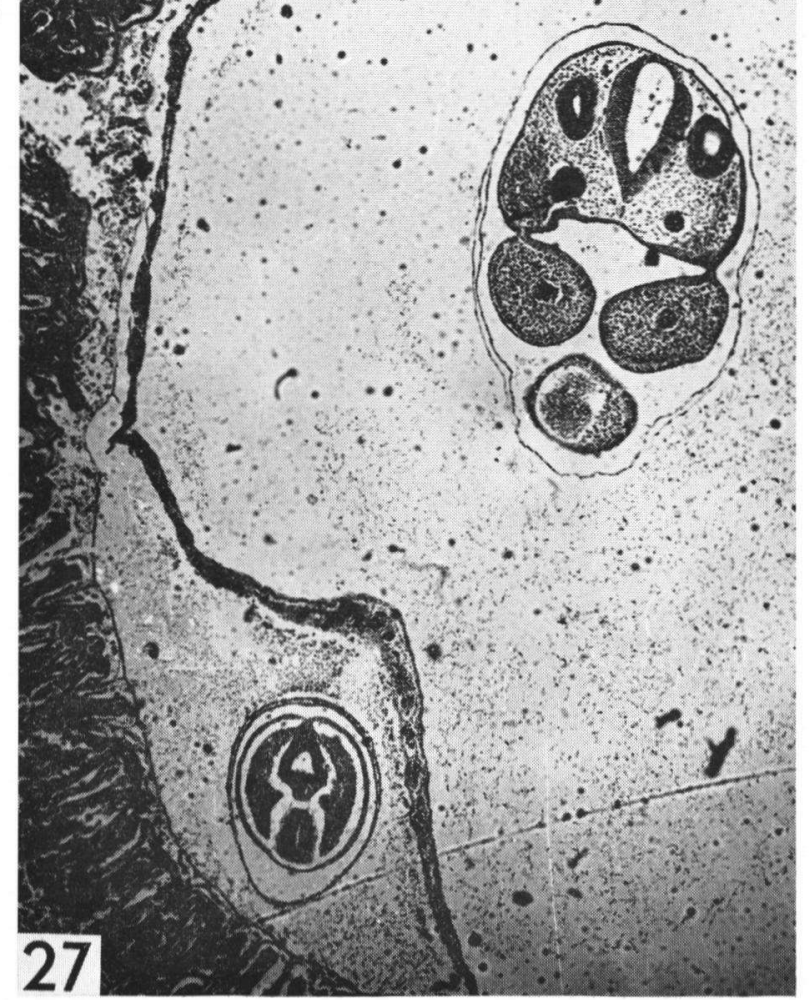


p40.

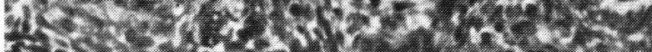

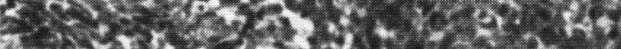

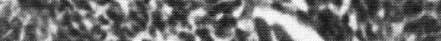

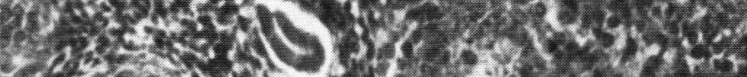

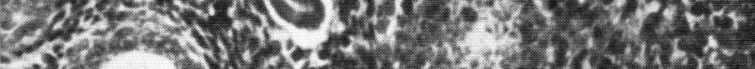

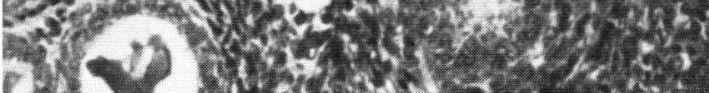

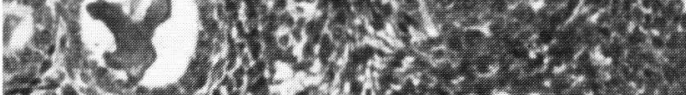

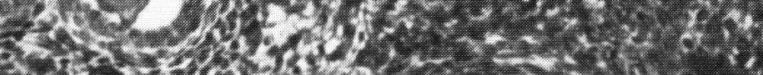

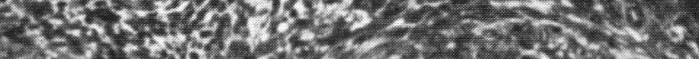

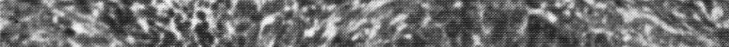

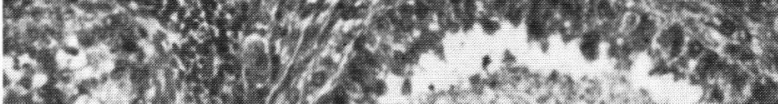
3.5. af. 6. $2030 \times 20$

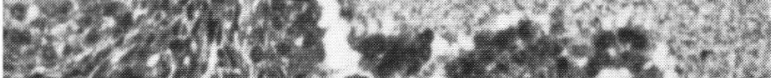
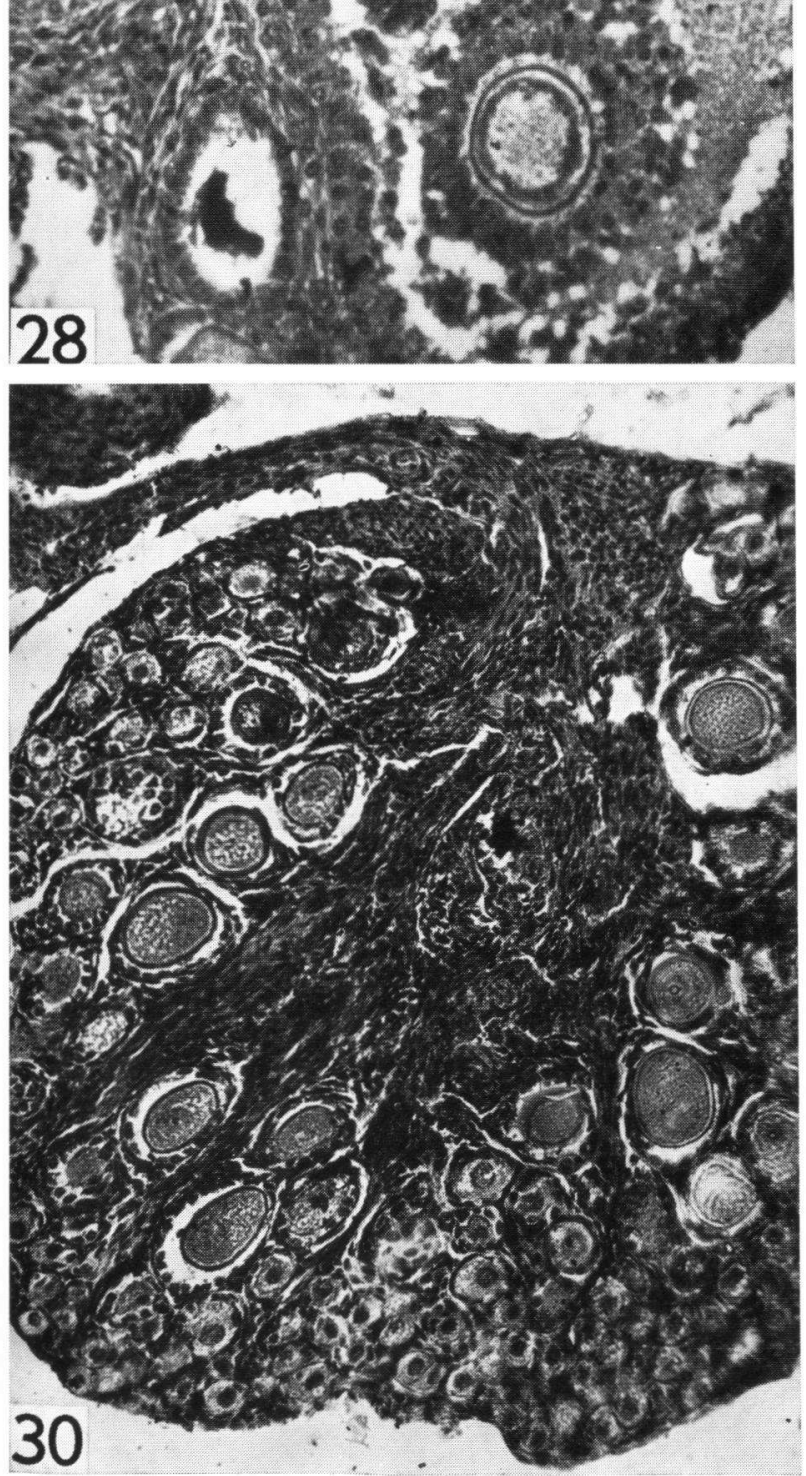
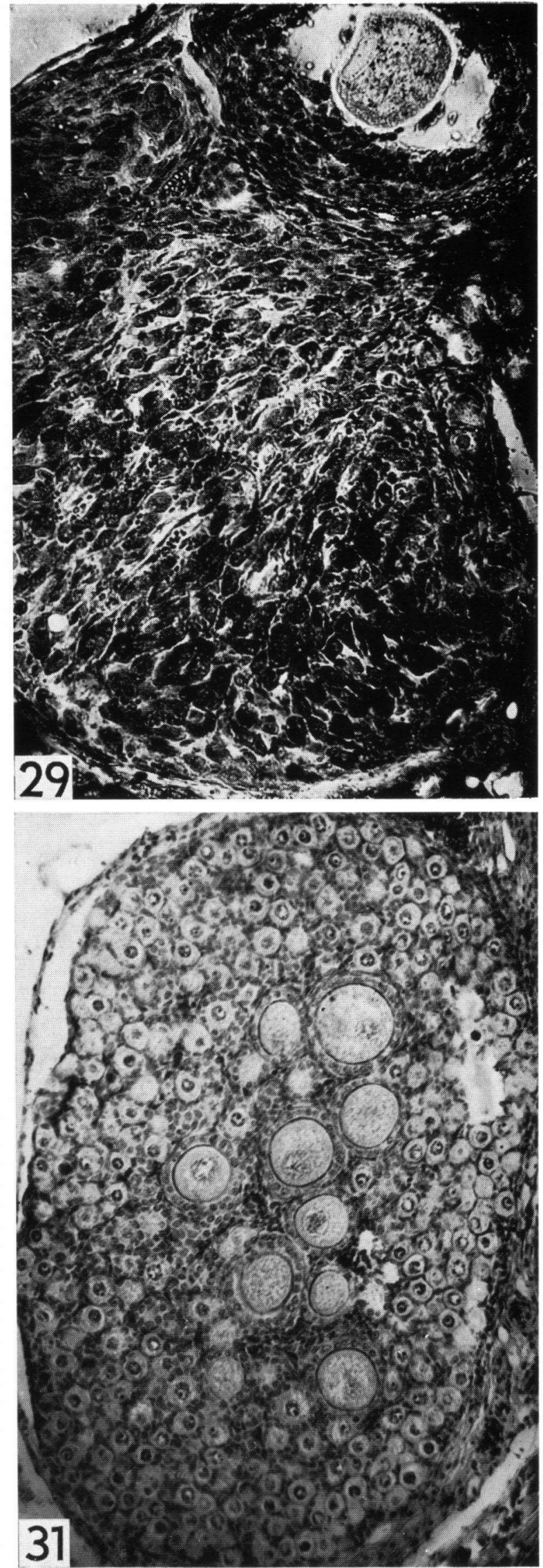

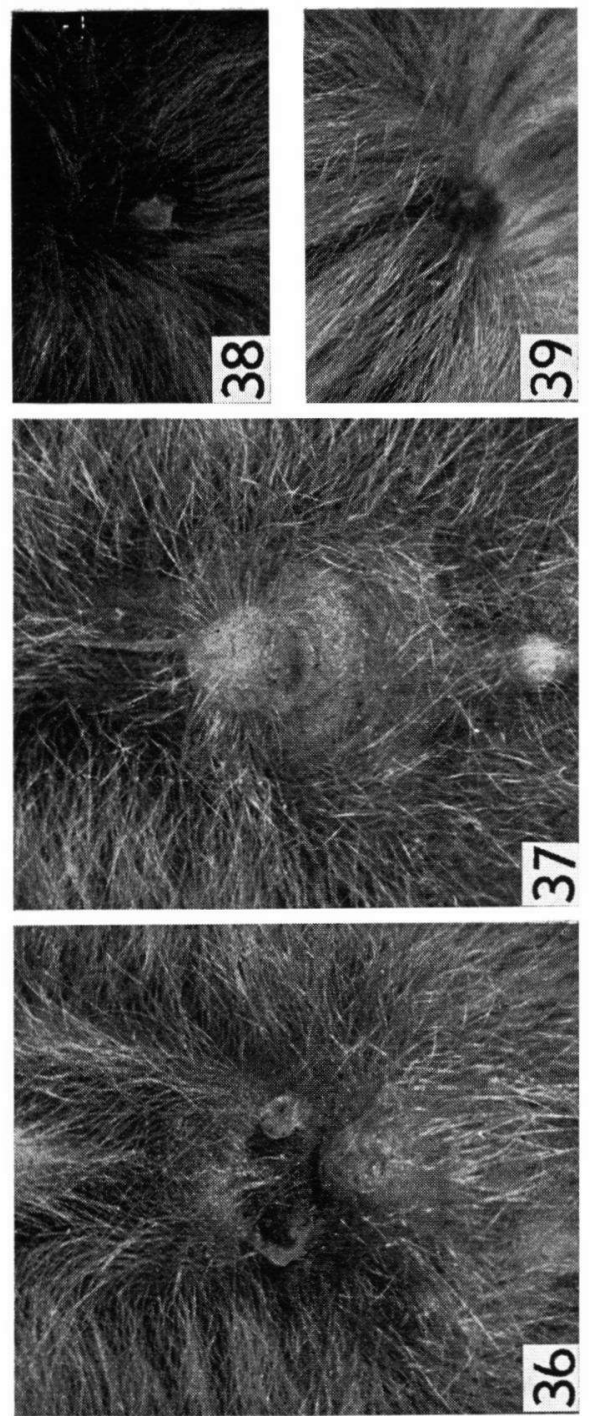

\section{5}
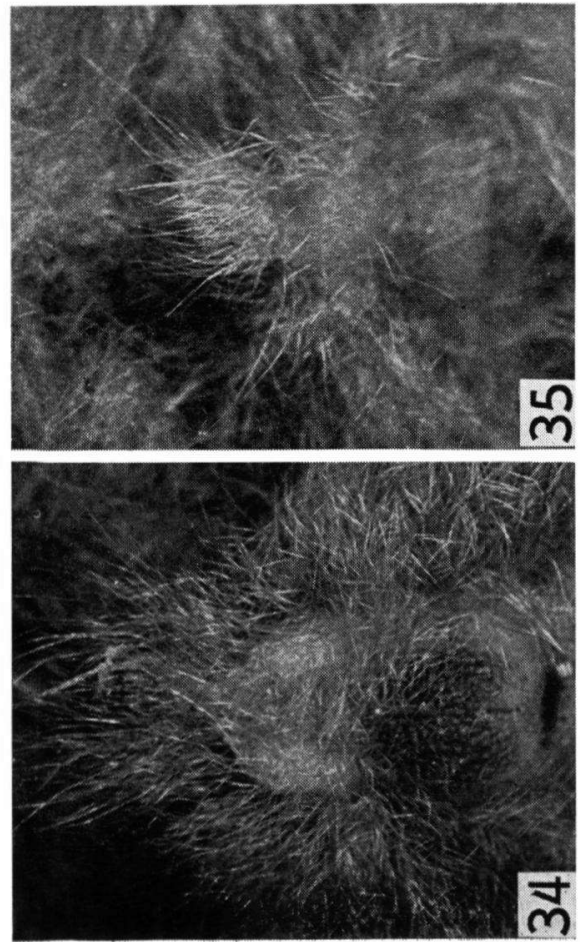